\title{
Dissolving Microneedle Patches for Dermal Vaccination
}

\author{
M. Leone' • J. Mönkäre' • J. A. Bouwstra' • G. Kersten ${ }^{1,2}$
}

Received: 20 April 2017 / Accepted: 26 June 2017 / Published online: 17 July 2017

(C) The Author(s) 2017. This article is an open access publication

ABSTRACT The dermal route is an attractive route for vaccine delivery due to the easy skin accessibility and a dense network of immune cells in the skin. The development of microneedles is crucial to take advantage of the skin immunization and simultaneously to overcome problems related to vaccination by conventional needles (e.g. pain, needle-stick injuries or needle re-use). This review focuses on dissolving microneedles that after penetration into the skin dissolve releasing the encapsulated antigen. The microneedle patch fabrication techniques and their challenges are discussed as well as the microneedle characterization methods and antigen stability aspects. The immunogenicity of antigens formulated in dissolving microneedles are addressed. Finally, the early clinical development is discussed.

KEY WORDS antigen stability · dissolving microneedle fabrication · dissolving microneedle characterization · skin immunization · vaccine delivery

\section{ABBREVIATIONS \\ Ad Adenovirus \\ AF4 Asymmetrical flow field-flow \\ fractionation \\ APCs Antigen presenting cells \\ B Brisbane}

J. A. Bouwstra and G. Kersten contributed equally to this work.

J. A. Bouwstra

bouwstra@lacdr.leidenuniv.nl

Division of Drug Delivery Technology, Cluster BioTherapeutics, Leiden Academic Centre for Drug Research, Leiden University Einsteinweg 55, P.O. Box 9502, 2300 RA Leiden, the Netherlands

2 Department of Analytical Development and Formulation, Intravacc Bilthoven, the Netherlands

$\begin{array}{ll}\text { CD } & \text { Circular dichroism } \\ \text { CpG ODN } & \text { CpG oligodeoxynucleotides } \\ \text { DAMPs } & \text { Damage-associated molecular pattern } \\ \text { DAB } & \text { Droplet-born air blowing } \\ \text { dDCs } & \text { Dermal dendritic cells } \\ \text { DEPA } & \text { Dissolving microneedles on an } \\ & \text { electrospun pillar array } \\ \text { DLS } & \text { Dynamic light scattering } \\ \text { dMNs } & \text { Dissolving microneedles } \\ \text { DT } & \text { Diphtheria toxoid } \\ \text { ELISA } & \text { Enzyme-linked immunosorbent assay } \\ \text { EV7I } & \text { Enterovirus 71 } \\ \text { FDA } & \text { Food and drug administration } \\ \text { HA } & \text { Hemagglutinin } \\ \text { HBV } & \text { Hepatitis B virus } \\ \text { HIV } & \text { Human immunodeficiency virus } \\ \text { HN } & \text { Hemagglutinin and neuraminidase } \\ \text { HP-SEC } & \text { Size exclusion chromatography } \\ \text { i.d. } & \text { Intradermal } \\ \text { i.m. } & \text { Intramuscular } \\ \text { IPV } & \text { Inactivated polio vaccine } \\ \text { LCs } & \text { Langerhans cells } \\ \text { MFI } & \text { Micro-flow imaging } \\ \text { MNs } & \text { Microneedles } \\ \text { MPLA } & \text { Monophosphoryl lipid A } \\ \text { Na-CMC } & \text { Sodium carboxymethylcellulose } \\ \text { NPs } & \text { Nanoparticles } \\ \text { NTA } & \text { Nanoparticle tracking analysis } \\ \text { OVA } & \text { Ovalbumin } \\ \text { PAA } & \text { Poly(acrylic acid) } \\ \text { PDMS } & \text { Polydimethylsiloxane } \\ \text { PGA } & \text { Polyglycolic acid } \\ \text { PLA } & \text { Polylactic acid } \\ \text { PLGA } & \text { Poly-D,L-lactide-co-glycolide } \\ \text { PMVE/MA } & \text { Methylvinylether-co-maleic } \\ \text { Poly(l:C) } & \text { Polyinosinic-polycytidylic acid } \\ & \end{array}$
\section{.}




$\begin{array}{ll}\text { PVA } & \text { Poly(vinylalcohol) } \\ \text { PVP } & \text { Poly(vinylpyrrolidone) } \\ \text { S.C. } & \text { Subcutaneous } \\ \text { SDS-PAGE } & \text { Sodium dodecyl } \\ & \text { sulfate-polyacrylamide gel electrophoresis } \\ \text { SRID } & \text { Single radial immunodiffusion assay } \\ \text { TEM } & \text { Transmission electron microscopy } \\ \text { TIV } & \text { Trivalent influenza vaccine } \\ T T & \text { Tetanus toxoid } \\ \text { UV-Vis } & \text { Ultraviolet-visible spectroscopy } \\ \text { VLP } & \text { Virus like particles } \\ \text { VNT } & \text { Virus neutralization test } \\ \text { VP } & \text { Virus particles }\end{array}$

\section{INTRODUCTION}

Vaccination is one of the most successful medical interventions in history, reducing mortality and morbidity for several infectious diseases to almost zero in areas where vaccines are being used $(1,2)$. Most vaccines are administered intramuscularly or subcutaneously (Fig. 1) by injection that may cause pain and discomfort and avoidance by people with needle-phobia (4-7). Furthermore, the hypodermic needles used to administer the vaccine by these routes generates hazardous waste and can lead to needle stick-injuries and needle re-use. The latter can spread infectious diseases such as Hepatitis B and AIDS particularly in the developing countries (8). Furthermore, the use of innovative vaccine delivery systems could offer several other advantages such as antigen thermostability, fewer booster immunizations and, as a consequence, increase of the vaccination adherence and a reduced burden on healthcare personnel. These latter advantages would especially be beneficial in mass vaccination campaigns, such as in case of outbreaks, when feasible and fast immunizations schemes are necessary (4).

Since the skin is a very immune-competent organ and easily accessible, dermal vaccine delivery is an attractive alternative. The viable epidermis and dermis contain many antigen presenting cells (APGs) such as Langerhans cells (LCs) and dermal dendritic cells (dDCs) (Fig. 1) $(9,10)$. These APCs capture antigens and subsequently migrate to the draining lymph nodes to present the antigen to the $\mathrm{T}$-cells to activate $\mathrm{Ag}$-specific $\mathrm{T}$-cells and B-cells for systemic immune response. Besides LCs and $\mathrm{dDC}$ s, epidermal keratinocytes are also involved in the immune response by producing cytokines and chemokines (e.g. TNF- $\alpha$ and IL-1 $\beta$ ) to enhance maturation of APCs and migration to the lymph nodes (11).
Although the skin surface is easily accessible, the skin (Fig. 1) is designed to protect the human body against entry of foreign organisms or toxic substances $(3,12)$. Therefore, the top-layer of the skin, the stratum corneum (in humans 15$20 \mu \mathrm{m}$ thick), forms a significant physical barrier for vaccine delivery. Consequently, the delivery of high-molecular weight (>500 Da) compounds such as antigens require methods enabling their penetration into the skin (13). Several methods such as powder and fluid jet injection, thermal microporation, sonoporation, transfollicular delivery and microneedles (9) have been proposed to deliver antigens into the skin. Recently, microneedles (MNs) have gained great attention for dermal vaccination. MNs are needle-like microstructures, up to $1 \mathrm{~mm}$ in length (3), typically assembled in variable numbers on a patch. They pierce the stratum corneum and underlying tissue to deliver the antigen into the epidermis or dermis while they are short enough not to reach pain receptors and thus pain sensation can be avoided (7). Furthermore, the immunization with MNs may not require the healthcare personnel $(5,6,11)$ and does not generate sharp needle wastage after immunization.

The first microneedles were conceptualized for drug delivery in 1976 (14) but only during the last 20 years microneedles have been actively developed. MNs can be classified in the following groups: hollow, coated, porous, hydrogel-forming, dissolving microneedles ( $\mathrm{dMNs}$ ) and MNs for pretreatment (15-18). dMNs consist of fastdissolving materials (e.g. polymers or sugars) as a matrix material and the drug/antigen is mixed in the matrix. After insertion into the skin, they dissolve releasing simultaneously the active pharmaceutical ingredient $(3,6,15,16,19)$.

The scope of this review is to evaluate the use of dMNs as vaccine delivery systems to overcome the limitations of traditional subcutaneous (s.c.), intramuscular (i.m.) or intradermal (i.d.) injections. Preparation methods for dMNs, their characterization and immunological properties will be described underlining the potential and novelty of this new micro-technology.

\section{MATERIALS AND MANUFACTURING METHODS}

\section{Materials}

Matrix material should possess the following characteristics: biocompatible, biodegradable, low toxicity, strength/ toughness and cheap $(17,20)$. Many materials have been used to produce dMNs (Table I). Head to head 
Fig. I Schematic representation of microneedle insertion and conventional (intramuscular, subcutaneous and intradermal) injections onto the human skin are shown. Microneedles penetrate the stratum corneum reaching the viable epidermis. The hypodermic needles puncture the skin during insertion into the subcutaneous or muscle tissues. Adapted from (3).

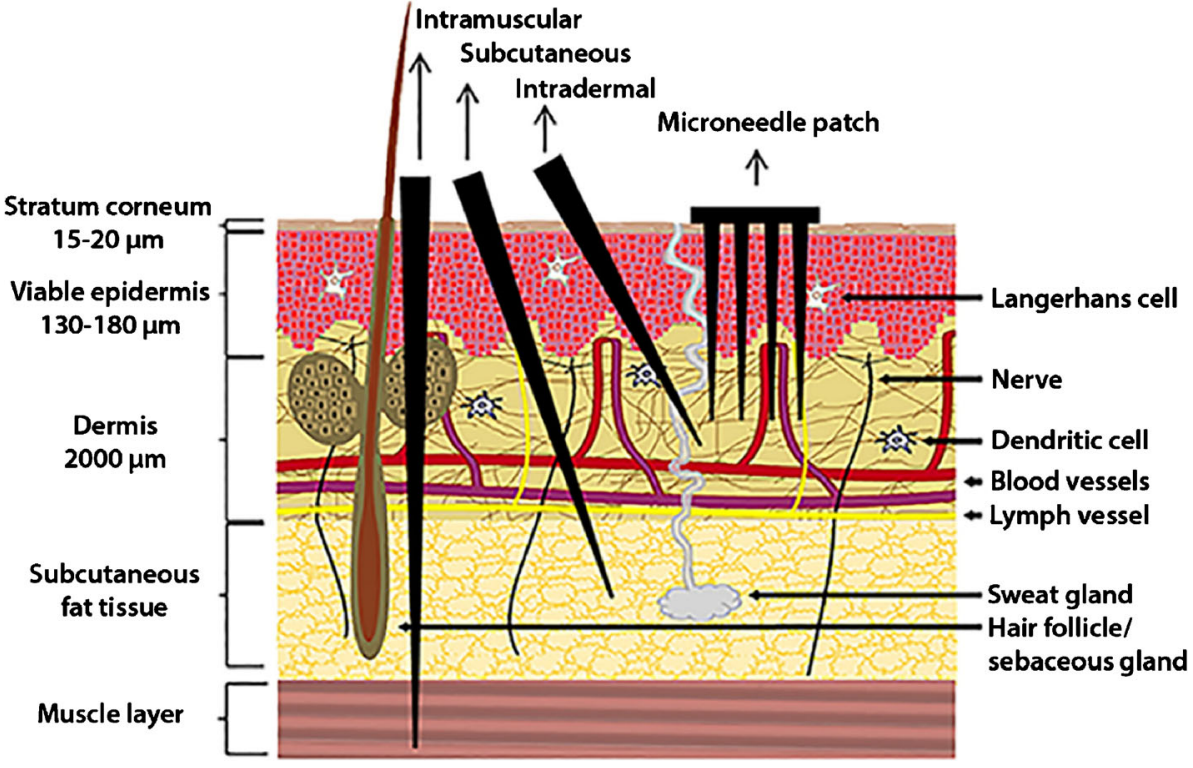

comparisons of the materials used for dMN production have not been reported as far as we know. The selection of the matrix material may be based on practical considerations rather than rational design. Apart from safety, factors to consider include obtaining MNs capable to pierce the skin, compatibility with the active compound, compatibility with the manufacturing procedure (acceptable viscosity before drying or spraying and reasonable solidification time) and a potential to scale-up of dMN patches for mass production (16). The most frequently used matrix materials are sodium hyaluronate, that is naturally present in the skin, and sodium carboxymethylcellulose (21-23,31-33). Both are approved as inactive materials by FDA for parenteral drug products. Other materials include poly(vinylalcohol) (PVA) (42), poly(vinylpyrrolidone) (PVP) (43), methylvinylether-co-maleic anhydride (PMVE/MA) (Gantrez AN-139 $\left.{ }^{\circledR}\right)(44,45)$ and low molecular weight sugars like maltose $(46,47)$ and trehalose (48). dMNs have also been prepared from biodegradable polymers such as polylactic-co-glycolic acid (PLGA) (46), polylactic acid (PLA) (49) and polyglycolic acid (PGA) (50). However, due to their slow dissolution rate in skin and a preparation method using high temperatures (34) and organic solvents, these polymers are less suitable as matrix material. The back-plate of the $\mathrm{dMN}$ patch can be made by using the same $(5 \mathrm{I})$ or different materials $(30,42)$ as the needles. Furthermore, the back-plate can be reinforced or the ease of handling can be increased by applying an adhesive tape $(38,42,52-54)$. Besides matrix material, other excipients might be included ((33) (32) (30)) to improve the antigen stability or mechanical strength of the dMNs (Table I).

Antigens that have been used include almost all vaccine types, ranging from peptides and proteins $(21-23)$ to DNA vectors encoding antigenic proteins $(27,33,41)$ and attenuated or inactivated viruses $(26,30,31)$. Antigens are generally dispersed directly in the $\mathrm{dMN}$ matrix $(21-23,31,32)$ but they can also be encapsulated in nanoparticles or in a cross-linked structure $(25,28,35)$ to potentiate or alter the immune response $(25,34,35)$. Furthermore, adjuvant can be incorporated in the dMNs (55).

\section{Manufacturing Methods}

\section{Micromolding}

The most common fabrication method of dMNs is micromolding in which $\mathrm{dMNs}$ are prepared using a polydimethylsiloxane (PDMS) mold (Fig. 2). First, the PDMS mold is typically produced from a silicon or metallic master mold (17) that is obtained by using techniques such as etching (56), lithography (57), thermal drawing (58) and laser micromachining $(59,60)$. PDMS is a hydrophobic flexible material, which can very accurately reproduce the master structure as a negative template (17). The mold can be re-used for dMN fabrications after appropriate cleaning. The first step in preparing dMNs using the PDMS mold is the addition of the polymer/antigen 
Table I Overview of Matrix Materials and Antigens Used for dMN Vaccination Studies. Back-Plate Materials are Not Listed in this Table

\begin{tabular}{|c|c|c|c|}
\hline dMN composition & Antigen (Ag) & Adjuvant (Adj) & Ref. \\
\hline Sodium hyaluronate & OVA & & $(2 \mathrm{l})$ \\
\hline Sodium hyaluronate & Adeno virus & & $(2 \mathrm{l})$ \\
\hline $\begin{array}{l}\text { Sodium hyaluronate, dextran } 70 \\
\text { and polyvidone }\end{array}$ & TT/DT & & $(22)$ \\
\hline Sodium hyaluronate & TT/DT & & $(23)$ \\
\hline Sodium hyaluronate & SE36 recombinant molecule (malaria vaccine) & & $(23)$ \\
\hline Sodium hyaluronate & Trivalent influenza & & $(23)$ \\
\hline Sodium hyaluronate & EV7I virus-like particles & & $(24)$ \\
\hline PVP & OVA & $\begin{array}{l}\text { CpG OND } \\
\text { Co-encapsulation in cationic liposome }\end{array}$ & $(25)$ \\
\hline PVP & Whole inactivated influenza virus & & (26) \\
\hline PVP & $\begin{array}{l}\text { Plasmid vector VR20 I } 2 \text { encoding the middle } \\
\text { envelope proteins of HBV }\end{array}$ & $\begin{array}{l}\text { CpG ODN } \\
\text { Co-encapsulation in cationic liposome }\end{array}$ & $(27)$ \\
\hline Gantrez ${ }^{\circledR}$ AN-139 & OVA & Encapsulation in PLGA NPs & $(28)$ \\
\hline Gantrez ${ }^{\mathbb{R}}$ AN-139 and polysorbate 80 & HIV-I CN54gp | 40 & MPLA & $(29)$ \\
\hline $\begin{array}{l}\text { Sucrose and threonine } \\
\text { Maltodextrin }\end{array}$ & IPV & & $(30)$ \\
\hline Sucrose, threonine and CMC & Live-attenuated measles vaccine & & $(31)$ \\
\hline $\mathrm{Na}-\mathrm{CMC}$ and trehalose & $\begin{array}{l}\text { Monovalent subunit influenza vaccine } \\
\text { Trivalent subunit influenza vaccine }\end{array}$ & & $(32)$ \\
\hline Na-CMC, sucrose and lactose & $\begin{array}{l}\text { Adenovirus expressing OVA } \\
\text { Adenovirus expressing HIV-I CN54 gag }\end{array}$ & & (33) \\
\hline PAA & OVA & Poly(l:C) loaded NPs & $(34)$ \\
\hline PAA & OVA & $\begin{array}{l}\text { Silk depot loading OVA } \\
\text { poly(I:C) }\end{array}$ & (35) \\
\hline Sodium chondroitin sulfate & OVA & & $(36)$ \\
\hline Chitosan & OVA & & $(37)$ \\
\hline Trehalose and PVA & Inactivated split trivalent influenza vaccine & & (38) \\
\hline Dextran 70 and sorbitol & Trivalent subunit influenza vaccine & & (39) \\
\hline Fish gelatin and sucrose & Subunit monovalent influenza vaccines & & $(40)$ \\
\hline PVA and sucrose & DNA plasmid expressing rabies $G$ protein & & $(4 \mid)$ \\
\hline
\end{tabular}

CPG ODN CPG oligodeoxynucleotides, DT diphtheria toxoid, EV7I Enterovirus 7I, Gantrez ${ }^{\circledR}$ AN-I39 copolymer of methylvinylether-co-maleic anhydride (PMVE/MA), HIV human immunodeficiency virus, HBV hepatitis B virus, IPV inactivated polio vaccine, MPLA monophosphoryl lipid A, NPs nanoparticles, Na-CMC Sodium carboxymethylcellulose, OVA ovalbumin, PAA poly(acrylic acid), PLGA poly-D,L-lactide-co-glycolide, poly(I:C) polyinosinic-polycytidylic acid, PVA poly(vinylalcohol), PVP poly(vinylpyrrolidone), $\pi$ tetanus toxoid

mixture in the mold. This is typically done manually at the research setting but the mold can also be filled by using an atomized spray (48). After filling of the mold, vacuum and/or centrifugation steps are performed to fill the PDMS microcavities with the polymer/antigen mixture (61). Finally, the solution in the mold is dried at slightly elevated temperature $(62,63)$. The drying step can be replaced by photopolymerization if photocrosslinkable material is used (60).

The micromolding can be a straightforward technique in the laboratory because it requires little additional equipment. Furthermore, the absence of harsh conditions (e.g. high temperature or organic solvents) is an advantage when working with sensitive antigens (64). However, it might not be suitable for industrial scale-up or continuous manufacturing if steps such as manual removal of air bubbles from the microcavities after vacuum or centrifugation are needed or if the production method will result in too much vaccine wastage (see Antigen Wastage section).

\section{Lithography}

Drawing Lithography. This technique is based on extensional (stretching) deformation of polymeric material from a 2dimensional to a 3-dimensional structure. Melted polymer is 
MICROMOLDING

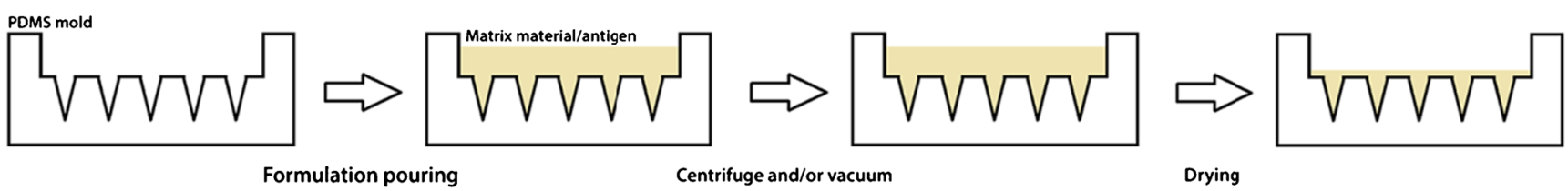

\section{DRAWING LITHOGRAPHY}

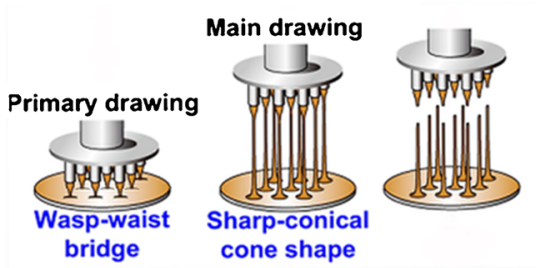

SOFT LITHOGRAPHY

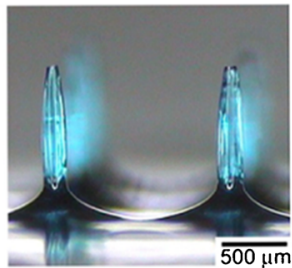

A

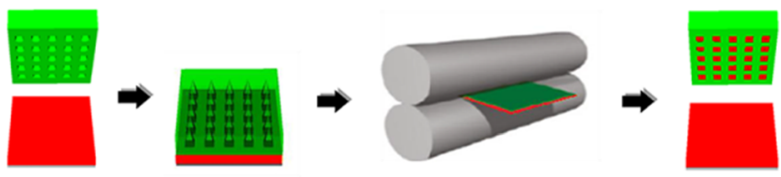

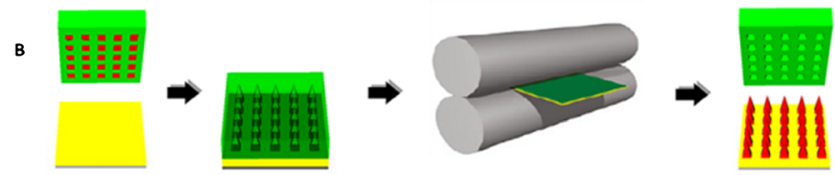

DAB
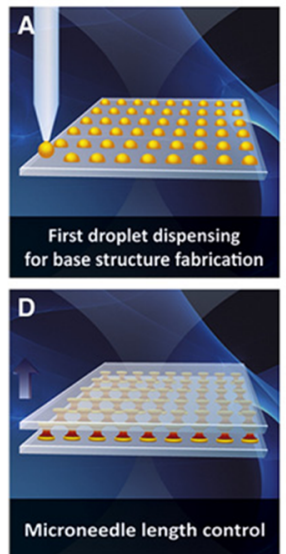
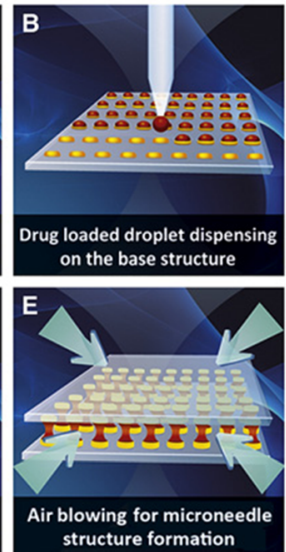
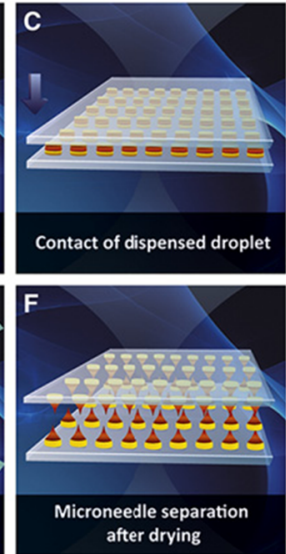

DEPA

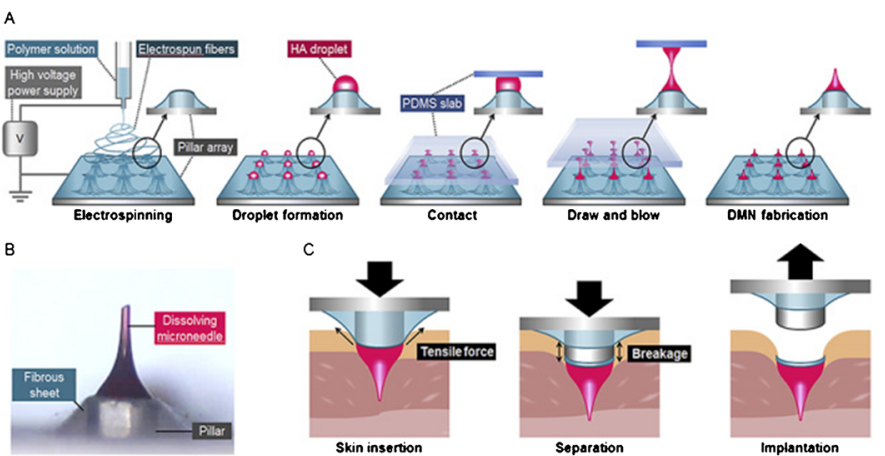

Fig. 2 dMN Manufacturing Methods. See main text for details. Adapted from (66-69). DAB = droplet-born air blowing; DEPA = dMN on an electrospun pillar array.

dispensed on a fixed plate and elongated by drawing pillars in the upper-moving plate (Fig. 2) (65,66). The polymer viscosity is progressively increased by cooling until the glass transition temperature of the polymer is reached. Finally, further cooling induces a solid polymer providing the suitable dMN strength for the skin piercing $(19,66)$. The advantage of this fast fabrication method is the minimal polymer wastage due to the dispensed drops on the plate. However, only a limited number of polymers have suitable glass transition temperatures for this method (65). More importantly, this technique is not appropriate for thermolabile antigens because melting and transition temperatures are high during the manufacturing (e.g. for maltose $\left.>95^{\circ} \mathrm{C}(66)\right)$.

Soft Lithography. In soft lithography dMNs are fabricated by first pairing a polymer film with the mold with microcavities and passing them through a heated nip.
Next, the filled mold is placed on a flexible, watersoluble substrate and passed through the heated nip. After separation of the mold, a dMN patch on the substrate remains (Fig. 2). Instead of heated nip, photocuring can be also used (67). Similarly to drawing lithography, this manufacturing method claims excellent scalability, low cost and short preparation time. However, the high temperature used for the fabrication can be still critical while using a thermolabile antigen mixed with the matrix.

\section{Droplet-Born Air Blowing and dMN on an Electrospun Pillar Array}

In droplet-born air blowing (DAB), a droplet of polymer solution without drug and another droplet of drug solution are dispensed together on two plates. The upper plate is moved downwards so that the droplets are 
touching and thereafter plates are withdrawn to a distance corresponding to the two dMN lengths of the lower and upper plate (Fig. 2). The polymer solutions are dried with air flow producing a dMN patch on each plate (Fig. 2) (68). The advantages include low temperature $\left(4-25^{\circ} \mathrm{C}\right)$ and fast $(\leq 10 \mathrm{~min})$ fabrication and minimal drug and polymer wastage.

A variant of $\mathrm{DAB}$ is $\mathrm{dMN}$ on an electrospun pillar array (DEPA). The flat plate is replaced here by a pillar array covered by a fibrous sheet. Then, polymer formulation droplets are dispensed on the pillar array and placed in contact with a PDMS slab to pull and elongate the droplets obtaining microneedles (Fig. 2). Finally, elongated droplets are dried by air flow.

\section{General Challenges of dMN Preparation}

\section{Antigen Wastage}

Dermal vaccination is attractive especially for the antigen dose sparing to evoke an immune response. However, the optimization of the manufacturing methods is crucial to reduce antigen wastage. During micromolding part of the antigen is lost in the PDMS mold due to low volume filling of the microcavities relative to the system volume needed (70). It is often mentioned that excess of solution from the mold can be collected in order to recycle $(35,51,63)$. However, the saved antigen amount is often not reported in the literature and more importantly the quality of the recovered antigen may be difficult to guarantee hampering reuse of the vaccine formulation.

One possibility to reduce the antigen loss during the micromolding is to use polymer/antigen solution only for the dMNs and to produce a backplate only from the matrix material or even from other material. The backplate material should possess higher viscosity than that of the needles to reduce the diffusion of the antigen from the $\mathrm{dMNs}$ during preparation and drying (51). In stability studies presence of antigen in the needles and its absence in the backplate should be monitored to demonstrate lack of diffusion of antigen to the backplate during storage (62). However, in literature this aspect is generally not addressed. In fabrication methods like drawing lithography, DAB and DEPA, the antigen is dispensed in drops, thus the antigen wastage can be potentially reduced drastically. However, it is not reported if antigen can be lost in the dispensing instrument.

\section{Antigen and Adjuvant Loading}

Besides reproducible loading (61) and dose homogeneity, dMNs should contain a sufficient high antigen and adjuvant dose, which can be challenging due to very low volumes of
$\mathrm{dMN}$ tips. This can be particularly challenging in the case of antigens encapsulated in nanoparticles, an approach to improve immunogenicity of dermally delivered subunit antigens (28). Another aspect to consider is the delivery efficiency, i.e. the relation between the antigen amount incorporated into the $\mathrm{dMNs}$ and the antigen dose actually delivered into the skin. Unfortunately, these aspects are often not described in detail in the literature, although systems have been and are in development to maximize delivery (see next section). This makes comparison of different concepts difficult if not impossible. An additional issue is the physico-chemical properties of the adjuvant, that determines whether the adjuvant can be mixed properly with the matrix material.

\section{Fabrication Aimed to Improve Delivery Efficiency}

In order to facilitate the delivery of the entire intended antigen dose into the skin, some modified fabrications have been developed. These include micromolding of arrowhead dMNs mounted on mechanically strong shafts $(37,63)$ or dMNs presenting an elongated base increasing the needle length (51). Drawing lithography has been modified by dispensing melted polymer on a fixed plate presenting pedestals (71). DEPA presents patch pillars to improve the delivery efficiency. After patch application into the skin, dMNs separate from the pillars due to a tensile breaking force of the fibrous sheet between the pillar and the dMN (Fig. 2). This allows a proper implantation of the dMNs into the skin and removal of the remaining back plate without the need to wait dMN dissolution (69).

\section{Antigen Degradation}

Other critical steps during the $\mathrm{dMN}$ preparation are related to the high temperature reached in some manufacturing methods. The micromolding usually is done at mild temperatures. However, when using methods such as drawing and soft lithography, temperatures around $100^{\circ} \mathrm{C}$ may be required. Such a temperature can be critical when using thermolabile antigens mixed to the matrix. Alternatively, photocurable polymers like acrylate-based polymers (72) and poly (ethylene glycol) diacrylate (PEGDA) (73-75) may be used. However, radiation should not damage proteins or DNA of vaccines. In all methods, a drying step is included which can be detrimental for protein antigens even at moderate temperatures (76).

\section{Sterility}

Because dMNs deliver antigen into the viable skin, they should be sterile and have low endotoxin content (77). Since the final product is dry, a sterile filtration step, if 
at all possible, should be done on final fluid bulk, implying that the actual patch manufacturing should be performed under aseptic conditions (77). Alternatively, sterilization of patches by gamma irradiation may be considered, although this can damage the antigen (77) and may be difficult to validate. Based on FDA guidelines for medical devices in direct contact with lymphatic tissue, the endotoxin content in dMNs should be $<20 \mathrm{EU} /$ device (78).

\section{CHARACTERIZATION OF DISSOLVING MICRONEEDLES}

A number of unique parameters must be determined to assess dMN quality (Table II). Since there are no licensed products on the market, no MN monographs exist in pharmacopoeias (79). Below, aspects that may be of importance are discussed.

\section{Appearance}

Shape and sharpness of MNs are typically investigated by microscopic techniques such as light and scanning electron microscopy (80-84). During product development, microscopy can be used also to analyze the distribution of fluorescent-labelled antigen in the MNs (61).

\section{Water Content}

$\mathrm{dMNs}$ are dry formulations and it is important to measure their water content by using methods such as Karl Fisher titration (a coulorimetric or volumetric titration to determine trace amounts of water in the sample), thermogravimetric analysis or moisture balance (85). The water content can influence mechanical properties, protein stability and dissolution kinetics (81). The generally recommended water content for freeze-dried vaccines is less than $3 \%(w / w)(79)$, that could be also taken as guideline for $\mathrm{dMNs}$.

\section{Antigen Stability}

Stability of the antigen should be assessed both after the manufacturing of dMNs (86) as well as after the storage $(22,24,31,38,39)$. The type of stability indicating assays depends on the antigen as well as the type of immunity that should be induced (e.g. for antibody responses the tertiary structure of protein is important). Protein conformation can be assessed by spectroscopic techniques such as
Table II dMN Characterization Methods

\begin{tabular}{|c|c|}
\hline Characteristic & Characterization method \\
\hline Appearance & Microscopy techniques \\
\hline $\begin{array}{l}\text { Antigen distribution in } \\
\text { MNs }\end{array}$ & Confocal microscopy \\
\hline \multirow[t]{3}{*}{ Water content } & Thermogravimetric analyser \\
\hline & Karl Fischer \\
\hline & Moisture balance \\
\hline \multirow[t]{4}{*}{ Antigen stability } & Immunogenicity \\
\hline & Antigenicity: ELISA, SRID, virus titration \\
\hline & Physico-chemical characterization: intrinsic fluorescence, CD, SDS-PAGE \\
\hline & Aggregation: HP-SEC, NTA, MFI, AF4, TEM, DLS \\
\hline Mechanical strength & Displacement-force test station \\
\hline Skin piercing efficiency & Skin staining and histological sections \\
\hline \multirow[t]{2}{*}{ Dissolution of MNs } & Dissolution of $\mathrm{MNs}$ in vitro \\
\hline & Change in $\mathrm{MN}$ tip length after skin insertion \\
\hline \multirow{2}{*}{$\begin{array}{l}\text { Antigen localization into } \\
\text { the skin }\end{array}$} & Microscope analysis of skin sections or confocal microscopy analysis of intact skin \\
\hline & Analysis of histological skin sections \\
\hline \multirow[t]{2}{*}{ Antigen quantification } & $\begin{array}{l}\text { Quantification of antigen concentration after in vitro dissolution of dMNs by suitable } \\
\text { methods (e.g. UV-vis, fluorescence or ELISA) }\end{array}$ \\
\hline & Quantification of antigen delivered into the skin by e.g. radioactivity or infrared imaging \\
\hline Stability after storage & Forced (elevated humidity and temperature) and real time stability testing \\
\hline
\end{tabular}

AF4 asymmetrical flow field-flow fractionation, CD circular dichroism, DLS dynamic light scattering, ELISA enzyme-linked immunosorbent assay, HP-SEC size exclusion chromatography, MFI micro-flow imaging, NTA nanoparticle tracking analysis, SDS-PAGE sodium dodecyl sulfate-polyacrylamide gel electrophoresis, SRID single radial immunodiffusion assay, TEM transmission electron microscopy, UV-Vis ultraviolet-visible spectroscopy 
circular dichroism (80) and fluorescence spectroscopy (61). Protein backbone integrity can be analyzed also by SDSPAGE (25). However, this method is not suitable to examine the protein unfolding, indicating the loss of B-cell epitopes. The obvious way to analyse B-cell epitopes is by measuring antigenicity with immunoassays such as ELISA. In case of incorporation of DNA in dMNs, agarose gel electrophoresis and in vitro transfection can be performed to measure the DNA supercoiling and efficacy respectively (41).

The aggregation of protein antigens or particulate vaccines can be investigated by several methods such as size exclusion chromatography (HP-SEC) (61), asymmetrical flow field-flow fractionation (AF4) (61), micro-flow imaging (MFI) (61), transmission electron microscopy (TEM) (24), dynamic light scattering (DLS) (24) and nanoparticle tracking analysis (NTA). For live attenuated or vector vaccines the viability of virus or bacterium may be sufficient because the antigen will replicate after immunization and so the vaccine potency can be determined by measuring the titer of live antigen (31). Finally, immunogenicity studies are crucial to determine vaccine potency (26). A limiting factor for characterization and quality control may be the small sample sizes and matrix effects due to high concentrations of matrix component after dissolution of the dMNs.

So far, a few studies have systematically analyzed vaccine stability in dMNs. Mistilis et al. showed that the buffer composition and preparation conditions (e.g. drying temperature) must be carefully selected to retain the vaccine stability of subunit influenza vaccine (85). ELISA analysis of hemagglutinin activity showed that ammonium acetate buffer ( $\mathrm{pH}$ 7.0) and HEPES retained the antigenicity much better in solution and dry state than when using phosphate-buffers. In addition, surfactants destabilized the antigen especially in liquid formulation prior to dMN fabrication and they may cause crystallization of the MN matrix damaging the antigen (85). Antigen encapsulation plays also a role in the antigen stabilization. Similar antigen-specific CD8+ proliferative responses for OVA-PLGA NPs in dMNs before and after 10 weeks storage at ambient conditions were obtained (28). In contrast, groups immunized with 10 weeks stored monomeric OVA in $\mathrm{dMNs}$ showed a decrease in T-cell response in comparison with the group immunized with non-stored one (28).

\section{dMN Mechanical Strength and Skin Penetration}

The mechanical properties of MNs (e.g. strength or facture force) should be analyzed to determine whether dMNs are strong enough and do not fracture during skin penetration
(87), unless it is intended so. Measurements of dMN displacement-force can be performed by using a displacement-force test station to compare different matrix materials or geometry $(80,83)$ or the effect of storage conditions (24). Subsequent skin penetration studies are typically analyzed on ex vivo human (61) or porcine skin (88). However, it is also important to consider the in vitro-in vivo correlation of the subcutaneous layers as these layers can also affect microneedle performance. For this purpose, artificial gel-layers can be used to resemble the in viwo situation more closely (89). After MN application and removal from the skin, the skin is stained with dye (e.g. trypan blue). Additionally, stratum corneum can be stripped and the number of penetrating tips per patch can be determined. The penetration of single MN through the skin layers can be examined in a detailed way by analysing histological cross-sections of skin, although this is a more laborious approach $(37,51,80)$ and not suitable for routine analysis. The depth of deposition of fluorescently-labelled antigen in the skin can be investigated by confocal microscopy (61) or fluorescence microscopy by using skin cryo-sections (24).

\section{dMN Dissolution}

The analysis of the dissolution process of $\mathrm{MNs}$ is crucial for reproducible antigen disposition in the skin. The $\mathrm{dMN}$ dissolution time can be investigated in vitro by immersing MNs in buffer (e.g. PBS) (82). This allows the assessment of the quantity and quality of the dissolved antigen. When focusing on dissolution in the skin, the optimal application time of $\mathrm{dMN}$ in the skin can be determined by analyzing MN length after the predetermined application periods $(24,80,81)$. The dMN dissolution in ex vivo skin typically resembles the in vivo use of MNs. However, it is important to analyze the dissolution also in preclinical studies and in the early clinical development because temperature and humidity conditions may be difficult to mimic in ex vivo conditions. Careful preclinical evaluation does not take away the need to study microneedle dissolution in a clinical setting. The contribution of physiological and mechanical properties of the skin at the application site (e.g. thickness, elasticity, etc) to the $\mathrm{dMN}$ dissolution rate and antigen delivery may be substantial and should be investigated in the future. Besides reproducible in vivo dissolution the actual dose delivered should be determined. Actual dose delivered can be substantially lower than the theoretical maximal dose since the base of the microneedle has a tendency not to dissolve completely. This is an economical risk. In that respect arrow-shaped microneedles having a smaller base, could have advantages above cone-shaped needles. 


\section{Quantification of Antigen/Adjuvant Dose}

\section{In Vitro Analysis}

The quantification of antigen dose in dMNs is often very challenging and it can be done in vitro by cutting the dMNs from the baseplate and dissolving them (81) or embedding the dMN patch in parafilm and allow MN tips to dissolve in PBS (90). Then, the antigen quantification can be performed for example by fluorescence $(81,90)$, UV-vis analysis (90) or ELISA. The antigen amount in the dMNs can be also determined by dissolving the entire patch (MNs and back-plate) and calculate the volume of the needles based on the needle dimensions. In this case, a prior analysis should demonstrate homogeneous antigen distribution in the entire patch. However, these in vitro techniques are difficult to validate. Furthermore, when using an adjuvant, this should also be quantified to confirm its dose, similarly to antigen.

\section{Ex Vivo and In Vivo Analysis}

The antigen dose delivered into the skin and the reproducibility of the antigen delivery can be determined in ex vivo or in vivo studies (63), either indirectly by measuring the remaining antigen in the dissolved MNs or directly by measuring the antigen in the skin. Direct quantification can be performed by using either radioactivity (91) or infrared imaging.

\section{IMMUNOGENICITY OF ANTIGENS ADMINISTERED BY DMNS: PRECLINICAL STUDIES}

The first successful vaccination with dissolving microneedles was reported in 2010 (55). Table III gives a summary of the reported immunization studies. Depending on the antigen, a humoral and/or cellular response is important for a therapeutic effect.

\section{Animal Models and Application Method}

Mice are the most frequently used animal model, particularly $\mathrm{BalB} / \mathrm{c}(23,25-27,29,32,36,38,40)$ or $\mathrm{C} 57 \mathrm{BL} / 6$ (21,28,33-35,55) strains. Transgenic T-cell receptor mouse models (e.g. OT-I mouse for examining $\mathrm{CD}^{+} \mathrm{T}$-cell response) can be also used as immunological model (92-94). However, animal models with skin anatomy that mimics more closely human skin may be more relevant, for example guinea pigs for influenza (39), beagle dogs for rabies vaccination (41) and rhesus macaques for measles and polio vaccination (30,31).

The dMN patch can be applied either manually, particularly if MN length is over $500 \mu \mathrm{m},(26-31,33,36,38,40,41)$ or by using an applicator $(21,22,25,37,39,55)$. The advantages of the manual application are simple administration and reduced costs (30). However, efficient skin piercing after manual application might be limited to longer MNs $(>550 \mu \mathrm{m})$ while shorter MNs $(300 \mu \mathrm{m})$ might require an applicator $(95,96)$. Besides the penetration efficiency, an applicator improves the reproducibility of the piercing, that is expected to lead to a more reproducible delivery of the vaccine (97).

\section{Humoral Immune Response}

\section{OVA}

The model antigen ovalbumin (OVA) is most commonly used in dMN immunization studies due to its relatively low cost and excellent stability (98) and the strong immunogenicity in mice. However, these beneficial characteristics mean that the results obtained with OVA may obscure formulation problems with more relevant vaccine antigens. Several studies with OVAcontaining dMNs have shown that IgG responses are either equal or superior to the ones obtained by s.c., i.m. or traditional i.d. injection of the same dose $(21,25,28,34,36,37,55)$. Furthermore, non adjuvanted OVA dMNs $(10 \mu \mathrm{g})$ showed a higher response than topical application of cholera toxinadjuvanted OVA $(100 \mu \mathrm{g})$ on intact skin (36). This indicates the importance of a direct delivery of the entire antigen dose into the skin to induce an immune response.

In another study, OVA loaded chitosan dMNs elicited higher IgG response than i.m. injection of OVA solution after single immunization in rats. This can be explained by a gradual degradation of chitosan microneedles creating a depot effect in the skin (37). The OVA containing chitosan microneedles were mounted on a PLA support. After application, the chitosan microneedle tips were released from the support, forming a depot in the skin. Even two weeks after the dMN application, chitosan and OVA were still present in rat skin. Similarly, single immunization with cross-linked silk/poly(acrylic acid) (PAA) dMNs evoked higher IgG response than the i.d. injection of OVA (35). However, in this case sustained release from the cross-linked silk in the PAA dMNs $(100 \%$ within 12 days) did not improve the response compared to fast release from PAA dMNs (100\% within 6 days). (35). Similarly, single immunization with Quil-A adjuvanted OVA dMNs resulted in stronger long-lasting IgG response than Quil-A adjuvanted OVA after i.m immunization (55). Twenty-eight days after a single immunization, dMNs (dose $7.6 \mu \mathrm{g}$ ) had similar IgG response to i.m injection $(15 \mu \mathrm{g})$ despite the lower dose. At day 102, the $\mathrm{IgG}$ response of dMNs $(7.6 \mu \mathrm{g})$ was higher than that of i.m $(15 \mu \mathrm{g})$, and even more interestingly low-dose dMNs $(0.4 \mu \mathrm{g})$ had similar response to i.m. immunization $(15 \mu \mathrm{g})$ (55). However, it must be noted that dMN patches were applied at two sites (both ears) while i.m injection was performed only at one site. Draining to two lymph nodes may have an effect on the 
Table III Immunization Studies with dMNs

\begin{tabular}{|c|c|c|c|c|c|c|}
\hline $\begin{array}{l}\text { Antigen/ Adjuvant } \\
\text { (dose) }\end{array}$ & Animal model & $\begin{array}{l}\text { Immunization site } \\
\text { and application } \\
\text { method }\end{array}$ & $\begin{array}{l}\text { Immunization } \\
\text { scheme }\end{array}$ & Immune response analyzed & dMNs result vs other groups & Ref. \\
\hline OVA I $\mu g$ & $\begin{array}{l}\text { C57BI/6 and Wistar } \\
\text { ST rats }\end{array}$ & $\begin{array}{l}\text { Back skin } \\
\text { Handheld } \\
\text { applicator }\end{array}$ & $\begin{array}{l}4 \text { times every } \\
2 \text { weeks }\end{array}$ & Ab response & $\begin{array}{l}\text { IgG levels equal or superior to } \\
\text { s.c. or i.d. group }\end{array}$ & $(2 I)$ \\
\hline $\begin{array}{l}\text { OVA } 10 \mu \mathrm{g} \\
\quad 100 \mu \mathrm{g}\end{array}$ & $\mathrm{BALB} / \mathrm{c}$ mice & $\begin{array}{l}\text { Dorsal skin } \\
\text { Manual application }\end{array}$ & $\begin{array}{l}2 \text { times every } \\
2 \text { weeks }\end{array}$ & Ab response & $\begin{array}{l}\text { IgG levels comparable } \\
\text { to i.d. group }\end{array}$ & $(36)$ \\
\hline $\begin{array}{l}\text { OVA I } 5 \mu \mathrm{g}, \\
50 \text { ng poly(l:C) } \\
\text { in PLGA NPs }\end{array}$ & $\mathrm{C} 57 \mathrm{BI} / 6$ & $\begin{array}{l}\text { Dorsal ear skin } \\
\text { No applicator } \\
\text { mentioned }\end{array}$ & $\begin{array}{l}2 \text { times every } \\
35 \text { days }\end{array}$ & $\mathrm{Ab}$ and $\mathrm{T}$-cell response & $\begin{array}{l}\text { IgG levels comparable to the } \\
\text { i.m. and i.d. groups at day } \\
63 \\
\text { CD8 }{ }^{+} \text {T-cells similar to i.d. } \\
\text { groups and higher than i.m. } \\
\text { after booster dose. } \\
\text { Central memory CD8 }{ }^{+} \\
\text {T-cells higher than i.d. and } \\
\text { i.m. groups }\end{array}$ & (34) \\
\hline $\begin{array}{l}\text { OVA } 9 \mu \mathrm{g} \\
\text { poly(l:C) I } 50 \mathrm{ng}\end{array}$ & C57BI/6 & $\begin{array}{l}\text { Dorsal ear skin } \\
\text { No applicator } \\
\text { mentioned }\end{array}$ & $\begin{array}{l}\text { Single vaccination } \\
\text { for dMNs } \\
\text { Boost on day } 28 \\
\text { for i.d. injection }\end{array}$ & $\mathrm{Ab}$ and $\mathrm{T}$-cell response & $\begin{array}{l}\text { Both } \mathrm{CD}^{+} \text {and } \operatorname{lgG} \text { response } \\
\text { higher than with i.d. injection } \\
\text { Central memory } \mathrm{CD} 8^{+} \text {T-cells } \\
\text { higher than i.d. group }\end{array}$ & (35) \\
\hline OVA I mg & $\begin{array}{l}\text { Sprague Dawley (SD) } \\
\text { rats }\end{array}$ & $\begin{array}{l}\text { Back skin } \\
\text { Homemade } \\
\text { applicator }\end{array}$ & Single vaccination & Ab response & $\begin{array}{l}\text { IgG levels higher than i.m. } \\
\text { group }\end{array}$ & (37) \\
\hline $\begin{array}{l}\text { OVA } 2 \mu \mathrm{g} \text { and } \\
\text { CpG OND } 10 \mu \mathrm{g} \\
\text { co-encapsulated in } \\
\text { cationic liposome }\end{array}$ & $\mathrm{BALB} / \mathrm{c}$ mice & $\begin{array}{l}\text { Abdomen skin } \\
\text { Homemade } \\
\text { applicator }\end{array}$ & $\begin{array}{l}2 \text { vaccinations after } \\
3 \text { weeks }\end{array}$ & Ab response & $\begin{array}{l}\text { IgG levels higher than i.m. } \\
\text { group }\end{array}$ & $(25)$ \\
\hline $\begin{array}{l}\text { PLGA NP-encapsulated } \\
\text { OVA } 10 \mu g\end{array}$ & $\mathrm{C} 57 \mathrm{BI} / 6$ & Manual application & Single vaccination & $\begin{array}{l}\text { T-cell response } \\
\text { and challange }\end{array}$ & $\begin{array}{l}\text { In dMN group: } \\
\text { CD8+ T-cell response with } \\
\text { central and effector memory } \\
\text { profiles. } \\
\text { Growth of melanoma tumor } \\
\text { through the Th I IFN-Y } \\
\text { mediated response } \\
\text { suppressed } \\
\text { Protection against respiratory } \\
\text { challenge with } \\
\text { OVA-expressing virus }\end{array}$ & $(28)$ \\
\hline $\begin{array}{l}\text { OVA7.6 } \mu \mathrm{g} \text { / Quil-A } \\
0.2 \mu \mathrm{g}(2 \text { patches per } \\
\text { mouse) }\end{array}$ & $\mathrm{C} 57 \mathrm{BI} / 6$ & Ventral ear skin & Single vaccination & Ab response & $\begin{array}{l}\text { IgG levels (lower dose than } \\
\text { i.m.) higher after } 102 \text { days } \\
\text { than im group }\end{array}$ & $(55)$ \\
\hline $\begin{array}{l}\text { OVA } 0.4 \mu \mathrm{g} \text { / Quil-A } \\
\text { 0.0I } \mu \mathrm{g} \\
\text { ( I patch per mouse) }\end{array}$ & & Spring applicator & & & $\begin{array}{l}\text { IgG levels (lower dose than } \\
\text { i.m.) comparable after } \\
\text { I02 days than i.m. group }\end{array}$ & \\
\hline $\begin{array}{l}\text { Split virus influenza } \\
\text { vaccine } 0.06 \mu \mathrm{g}\end{array}$ & $\mathrm{C} 57 \mathrm{BI} / 6$ & Ventral ear skin & Single vaccination & Ab response & $\begin{array}{l}\text { IgG levels (lower dose than } \\
\text { i.m.) lower than i.m. group }\end{array}$ & $(55)$ \\
\hline
\end{tabular}

(I patch per mouse)

Split virus influenza

vaccine $0.12 \mu \mathrm{g}$

(2 patch per mouse)

Inactivated Influenza

Virus $6 \mu \mathrm{g}$

$\mathrm{BALB} / \mathrm{c}$ mice

Spring applicator

Dorsal skin

Manual application

Inactivated split TIV

$0.375 \mu \mathrm{g} \mathrm{HA}$
$\mathrm{BALB} / \mathrm{c}$ mice

Ear
Single vaccination

$\mathrm{Ab}$ response
Single vaccination $\quad A b$ and $T$-cell response
IgG levels slightly lower (after 14 days) and then similar (after 28 days) than i.m. group

$\mathrm{HAl}$ similar to i.m. group

Cellular response similar to the i.m. route

Anti-HA IgG response higher than i.m. group 
Table III (continued)

\begin{tabular}{|c|c|c|c|c|c|c|}
\hline $\begin{array}{l}\text { Antigen/ Adjuvant } \\
\text { (dose) }\end{array}$ & Animal model & $\begin{array}{l}\text { Immunization site } \\
\text { and application } \\
\text { method }\end{array}$ & $\begin{array}{l}\text { Immunization } \\
\text { scheme }\end{array}$ & Immune response analyzed & $\mathrm{dMNs}$ result vs other groups & Ref. \\
\hline $\begin{array}{l}\text { Inactivated split } \\
\text { TN } 3 \mu \mathrm{g} \mathrm{HA}\end{array}$ & & Manual application & & & $\begin{array}{l}\text { Anti-HA IgG comparable but } \\
\text { more durable than i.m } \\
\text { group } \\
\text { HI titers comparable to i.m. } \\
\text { group }\end{array}$ & \\
\hline $\begin{array}{l}\text { Influenza vaccine } \\
\text { HINI } 0.1 \text { and } \\
\text { I } \mu \mathrm{g} H \mathrm{HA}\end{array}$ & BALB/c mice & Not reported & $\begin{array}{l}2 \text { times after } \\
4 \text { weeks }\end{array}$ & Ab response & $\begin{array}{l}\mathrm{HI} \text { and } \operatorname{lgG} \text { titers higher than } \\
\text { i.m. group } \\
\text { Microneutralization titers } \\
\text { lower than i.m. group }\end{array}$ & (32) \\
\hline TIV $0.1 \mu \mathrm{g} H \mathrm{~A}$ & & & & & $\begin{array}{l}\text { HI titers after the boost lower } \\
\text { than i.m. group }\end{array}$ & \\
\hline $\begin{array}{l}\text { Cell culture-derived } \\
\text { influenza subunit } \\
\text { trivalent vaccine } \\
3 \times 2.5 \mu \mathrm{g} \mathrm{HA} \text { and } \\
3 \times 10.8 \mu \mathrm{g} \mathrm{HA}\end{array}$ & Hartley guinea pigs & $\begin{array}{l}\text { Dorsal skin } \\
\text { Spring-based } \\
\text { applicator }\end{array}$ & $\begin{array}{l}2 \text { times after } \\
3 \text { weeks }\end{array}$ & Ab response & $\begin{array}{l}\text { IgG and HI titers comparable to } \\
\text { i.m. group }\end{array}$ & $(39)$ \\
\hline HINI $3 \mu \mathrm{g}$ of HA & $\mathrm{BALB} / \mathrm{c}$ mice & Dorsal skin & Single vaccination & Ab response & $\begin{array}{l}\text { HAl, IgG and VNT higher than } \\
\text { i.m. group }\end{array}$ & $(40)$ \\
\hline $\mathrm{H} 3 \mathrm{~N} 23 \mu \mathrm{g}$ of $\mathrm{HA}$ & & Manual application & & & $\begin{array}{l}\text { HAl titers higher than i.m. } \\
\text { group } \\
\text { VNT and IgG titers similar to } \\
\text { i.m. group }\end{array}$ & \\
\hline B $3 \mu \mathrm{g}$ of $\mathrm{HA}$ & & & & & $\begin{array}{l}\text { HAl, lgG and VNT higher than } \\
\text { i.m. group }\end{array}$ & \\
\hline $\begin{array}{l}\text { Ad type } 5 \text { - OVA } \\
\quad \text { vector }\left(4.3 \times 10^{8} \mathrm{VP}\right)\end{array}$ & $\mathrm{C} 57 \mathrm{BI} / 6$ and $\mathrm{B} 6$ & $\begin{array}{l}\text { Dorsal surface of } \\
\text { the foot, ear or } \\
\text { back skin }\end{array}$ & Single vaccination & T-cell response & $\begin{array}{l}\text { SIINFEKL- specific CD8+ } \\
\text { T-cells indistinguishable with } \\
\text { i.d., s.c. and i.m. groups }\end{array}$ & (33) \\
\hline $\begin{array}{l}\text { Ad type } 5-\mathrm{HIV} / g a g \\
\text { vector }\left(4.3 \times 10^{8} \mathrm{VP}\right)\end{array}$ & & Manual application & & & $\begin{array}{l}\text { CD8 + T-cell frequencies } \\
\text { comparable with i.d. group }\end{array}$ & \\
\hline $\operatorname{Ad}\left(7.7 \times 10^{9} \mathrm{VP}\right)$ & Hairless rats & $\begin{array}{l}\text { Back skin } \\
\text { Handheld } \\
\text { Applicator }\end{array}$ & $\begin{array}{l}3 \text { times after } \\
2 \text { weeks }\end{array}$ & Ab response & IgG titers equal to s.c. group & $(2 \mid)$ \\
\hline EV7I VLP I $\mu g$ & BALB/c mice & Applicator & $\begin{array}{l}3 \text { times after } \\
2 \text { weeks }\end{array}$ & $\begin{array}{l}\text { Ab, T-cell response and } \\
\text { challenge }\end{array}$ & $\begin{array}{l}\text { IgG and VNT comparable to } \\
\text { i.m. }(10 \mu \mathrm{g}) \text { and higher than } \\
\text { s.c. }(10 \mu \mathrm{g}) \text { after the third } \\
\text { vaccination } \\
\text { I00\% survival after challenge } \\
\text { Stronger T-cell response than } \\
\text { i.m. and s.c. (both } 10 \mu \mathrm{g})\end{array}$ & $(24)$ \\
\hline $\begin{array}{l}\text { IPV type I } \\
\text { (47 D-antigen units) } \\
\text { IPV type } 2 \\
\text { (9 D-antigen units) }\end{array}$ & Rhesus Macaques & $\begin{array}{l}\text { Upper back skin } \\
\text { Manual application }\end{array}$ & $\begin{array}{l}2 \text { times after } \\
8 \text { weeks }\end{array}$ & Ab response & $\begin{array}{l}\text { No difference in } \lg G \\
\text { responses with i.m. group } \\
\text { No difference in lgG } \\
\text { responses with i.m. group }\end{array}$ & (30) \\
\hline $\begin{array}{l}\text { IPV type } 3 \\
\quad \text { (38 D-antigen units) }\end{array}$ & & & & & $\begin{array}{l}\text { IgG lower than in the i.m. } \\
\text { group. } \\
\text { This difference is due to a } \\
\text { mistake in the IPV type } 3 \\
\text { quantification: the real dose } \\
\text { in the patch was } 3 \times \text { lower } \\
\text { than } 38 \text { D-antigen units }\end{array}$ & \\
\hline $\begin{array}{l}\text { Divalent toxoid } \\
\text { vaccine (TT } 20 \mu \mathrm{g} \\
\text { and DT } 10 \mu \mathrm{g})\end{array}$ & Wistar ST rats & $\begin{array}{l}\text { Back skin } \\
\text { Handheld } \\
\text { applicator }\end{array}$ & $\begin{array}{l}5 \text { times after } \\
2 \text { weeks }\end{array}$ & Ab response & $\begin{array}{l}\text { Both anti-TT and anti-DT } \\
\text { IgG titers after dMNs } \\
\text { stored vaccination } \\
\text { comparable with those } \\
\text { induced by freshly } \\
\text { prepared dMNs. }\end{array}$ & (22) \\
\hline
\end{tabular}


Table III (continued)

\begin{tabular}{|c|c|c|c|c|c|c|}
\hline $\begin{array}{l}\text { Antigen/ Adjuvant } \\
\text { (dose) }\end{array}$ & Animal model & $\begin{array}{l}\text { Immunization site } \\
\text { and application } \\
\text { method }\end{array}$ & $\begin{array}{l}\text { Immunization } \\
\text { scheme }\end{array}$ & Immune response analyzed & $\mathrm{dMNs}$ result vs other groups & Ref. \\
\hline $\begin{array}{l}\text { Measles Vaccine } \\
\qquad(3100 \text { TCID50) }\end{array}$ & Rhesus Macaques & $\begin{array}{l}\text { Upper back skin } \\
\text { Manual application }\end{array}$ & Single vaccination & Ab response & $\begin{array}{l}\text { VNT titers equivalent to } \\
\text { that of s.c. group }\end{array}$ & $(31)$ \\
\hline $\begin{array}{l}\text { Vector encoding the } \\
\text { middle envelope } \\
\text { proteins of HBV } \\
10 \mu \mathrm{g}\end{array}$ & BALB/c mice & Abdominal skin & $\begin{array}{l}2 \text { times after } \\
3 \text { weeks }\end{array}$ & Ab response & IgG comparable to i.m. group & (27) \\
\hline $\begin{array}{l}\text { CpG ODN } 10 \mu \mathrm{g} \\
\text { Encapsulation (with or } \\
\text { without Adj) in } \\
\text { cationic liposomes }\end{array}$ & & Manual application & & & & \\
\hline $\begin{array}{l}\text { DNA plasmid } \\
\quad \text { expressing rabies } \mathrm{G} \\
\text { protein } 50 \mu \mathrm{g}\end{array}$ & Beagle dogs & Inner ear pinna & $\begin{array}{l}2 \text { times after } \\
4 \text { weeks }\end{array}$ & Ab response & $\begin{array}{l}\text { VNT titers comparable } \\
\text { ( } 42 \text { days after the prime) and } \\
\text { higher ( } 56 \text { days after the } \\
\text { prime) than i.m. group }\end{array}$ & $(4 I)$ \\
\hline $\begin{array}{l}\text { DNA plasmid } \\
\text { expressing rabies } \mathrm{G} \\
\text { protein } 5 \mu \mathrm{g}\end{array}$ & & $\begin{array}{l}\text { Application by } \\
\text { thumb }\end{array}$ & & & $\begin{array}{l}\text { VNT titers lower than i.m. } \\
\text { group }\end{array}$ & \\
\hline $\begin{array}{l}\text { HIV-I CN54gp I } 40 \\
\quad \text { I } 0 \mu \mathrm{g} \text { MPLA }(20 \mu \mathrm{g})\end{array}$ & $\mathrm{BalB} / \mathrm{C}$ & $\begin{array}{l}\text { Ear } \\
\text { Application by } \\
\text { thumb }\end{array}$ & $\begin{array}{l}4 \text { times after } \\
2 \text { weeks }\end{array}$ & Ab response & IgG titers lower than s.c. group & (29) \\
\hline
\end{tabular}

Ad adenovirus, B Brisbane, CPG ODN CpG oligodeoxynucleotides, DT diphtheria toxoid, EV7I Enterovirus 7I, HA hemagglutinin, HBV hepatitis B virus, HIV human immunodeficiency virus, HN hemagglutinin and neuraminidase, IPV inactivated polio vaccine, MPLA monophosphoryl lipid A, NPs nanoparticles, OVA ovalbumin, PLGA poly-D,L-lactide-co-glycolide, poly(I:C) polyinosinic-polycytidylic acid, TIV trivalent influenza vaccine, $T T$ tetanus toxoid, VLP virus like particles, VNT virus neutralization test, VP virus particles

magnitude of the response. Also, the ear is a very sensitive location for dermal vaccination probably for the short distance to one major draining lymph node (99).

The use of dMNs have been shown to affect the Th1/Th2 balance. Single immunization with cross-linked silk/PAA $\mathrm{dMNs}$ evoked strong IgG1 and IgG2c response while i.d. injection elicit only IgG1 response, and thus dMN immunization shifted Th1/Th2 balance toward Th1 (35). These results were supported by another study where hyaluronan-based OVA dMNs were compared to s.c. and i.d. injections in mice (21). In contrast, in rats no IgG2c response was detected neither after $\mathrm{dMN}$, s.c., or i.d. immunization in the same study (21). Additionally, in another study the shift in Th1/Th2 balance was not observed after $\mathrm{dMN}$ immunization in mice (25). As conclusion, dMN vaccination may affect the Th1/Th2 balance but further studies are needed since the number of publications on this subject is limited.

\section{Influenza}

Immunization with influenza vaccine loaded $d M N_{s}$ resulted often in higher ((38) (40)) or comparable (26) IgG response than i.m. administration. However, Kommareddy et al. showed that $\mathrm{dMNs}$ evoked lower IgG response than i.m. immunization after the boost, although the response induced by dMNs was higher after the prime (32). However, in other studies contradicting results were found. Haemagglutination inhibition titers and antibodies and neutralizing antibody titers after the dMN immunization were similar (26) or superior (40) to i.m. immunization. Stabilization of the antigen by addition of sucrose (40) may have allowed to obtain a higher antibody titers than the previous work (26). Furthermore, the difference with the above mentioned study (32) could be explained by the use of a different assay (ELISA assay) than the one routinely used to investigate the influenza vaccine quality (single radial immunodiffusion (SRID) assay). Interestingly, the dry matrix of dMNs can stabilize the antigen up to one year in comparison to liquid formulation (38). In summary, most studies show that influenza vaccination by dMNs can evoke comparable or even superior responses than i.m. immunization.

\section{Other Antigens}

Different types of antigen, such as vector, live attenuated and inactivated vaccines, have been loaded in $\mathrm{dMNs}$ and evaluated in vivo. An example is the vaccination of rats with the model antigen adenovirus (Ad) loaded dMNs: Ad-specific IgG titers observed were comparable to the s.c. group, while topical application showed no IgG response (21). In a study examining the dose-sparing effect, mice were immunized with dMNs loaded with 1/10th the dose of Enterovirus7 1 (EV71) - viruslike particles compared to immunization with a full dose i.m. 
and s.c. injected vaccine. Antibody and neutralizing titers both revealed comparable responses to i.m. and higher responses than s.c. after the three immunizations. Furthermore, the $\mathrm{dMN}$ group, together with s.c. and i.m. groups, survived the lethal virus challenge showing the protective effect of the dMNs (24). Rhesus macaques were used as animal model to examine the immune response after vaccination with inactivated polio vaccine (IPV) (30) and live-attenuated measles vaccine (31). In both cases, neutralizing antibody titers after dMN immunization were comparable to that after s.c. (measles) and i.m. (IPV) immunization.

In the case of dMNs loaded with DNA containing the rabies G-protein gene, comparable neutralizing antibody titers with i.m. were detected after a booster. No evidence of the dose sparing in dMNs was found since the antibody titers of 10-fold lower dose were clearly weaker than those of full dose in $\mathrm{dMNs}$ (41). The co-encapsulation of plasmid vector against hepatitis $\mathrm{B}$ virus $(\mathrm{HBV})$ and $\mathrm{CpG}$ in cationic liposomes in $\mathrm{dMN}$ sesulted in slightly higher IgG titers than free antigen and adjuvant in $\mathrm{dMNs}$ (27). It should be considered that the characteristics of liposomes changed after loading in $\mathrm{dMNs}$ (increase in size and decrease in Z-potential). However, the immune responses were generally similar between $\mathrm{dMN}$ and i.m immunization, and adjuvant and liposomes did not affect the IgG1/IgG2a balance (27).

\section{Cellular Immune Response}

De Muth et al. have reported two studies in which dMN immunization elicited high CD8+ T-cell responses. Mice were immunized with dMNs made of fast-dissolving PAA containing OVA mixed with PLGA microparticles (size $1.6 \mu \mathrm{m}$ ) encapsulating poly(I:C) (34) or cross-linked silk structure of OVA and poly(I:C) (35). The latter results in a binary release profile: a burst of OVA after dMN dissolution followed by a sustained OVA release from the cross-linked silk structure. Both studies indicated that the CD8+ T-cells producing IFN- $\gamma$ and TNF- $\alpha$, upon peptide stimulation, are increased by dermal sustained release $(>16$ days) from $\mathrm{dMNs}$ in comparison with i.m. injection of sustained release of poly $(\mathrm{I}: \mathrm{G})$ from PLGA microparticles (34), or with i.d. injection of soluble OVA and poly(I:C) (35). Furthermore, when comparing the different dMNs, the sustained release of cross-linked silk/PAA microneedles additionally increased the CD8+ response in comparison with fast release of PAA microneedles (35). In addition, a prime immunization with $\mathrm{dMN}_{\mathrm{s}}$ can produce a similar fraction of functional CD8+ T-cells as a prime and boost with i.d. injection (35). Despite a larger effector CD8+ $\mathrm{T}$-cell response, $\mathrm{dMN}$ delivery also resulted in a more rapid transition to central memory CD8+ T-cells than i.m. and i.d. injections, suggesting the additional expansion of CD8+ Tcells after dMN delivery did not solely result in more terminally differentiated effector cells (34) (35). However, sustained release from dMNs did not further improve the memory response (35). A long-term memory immune response was reported also after vaccination by $\mathrm{Na}-\mathrm{CMC}$ dMNs loading recombinant adenovirus vector encoding HIV-1 gag. Vaccination by dMNs generated CD8+ memory T-cells comparable with the intradermal injection (100). Supporting results have been found also with other MN technologies inducing a better long-term memory response than s.c. (101) or i.d. (102) injections.

The PLGA NPs dMN concept may have potential for therapeutic cancer vaccination: dMN immunization suppressed the growth of melanoma tumor, evoked in mice by injecting OVA-tumor cells, through antigen-specific CD8+ T cells (28). Furthermore, OVA-PLGA NPs dMN immunization protected against respiratory viral challenge with a recombinant Sendai virus expressing OVA (28). The vaccine depot and particulate vaccines may induce a better T-cell immune protection because the response correlates with antigen persistence (103), the sustained antigen release (104) or particulate nature of vaccine. To elucidate the immunological mechanism, it was shown that Langerhans cells are required for cytotoxic CD8+ responses (28) (105). Langerhans cells apparently efficiently process the OVA loaded in the microparticles which leads to cross presentation by MHC class I molecules. To support this explanation, the role of Langerhans cells was less significant for soluble OVA compared to particulate OVA (105).

In another study with dMNs loaded with EV71 virus-like particles, vaccination by $\mathrm{dMN}$ s loading 10 times lower antigen dose than i.m. and s.c. injections could promote stronger EV71specific T-cell response than the conventional injections (24).

Viral vectors are able to induce strong T-cell responses after dMN immunization. dMNs with human adenovirus expressing ovalbumin were compared to i.d, i.m. and s.c. injections. The T-cell responses were similar in all groups (33). Similarly, CD8+ T-cell responses were comparable after mice were immunized with rAdHu5 vector encoding a HIV-1 Gag gene by dMNs or i.d. injection (33).

\section{dMN Immunization: Factors Influencing the Immunogenicity}

\section{Adjuvants}

Several adjuvants have been used in $\mathrm{dMNs}$ and they are similar to those used for other administration routes except aluminum based adjuvants and emulsions. Aluminium based adjuvants may cause local adverse effects like granuloma formation and therefore is not suitable for delivery to the skin (106). Emulsions cannot be formulated in dry formulations like $\mathrm{dMN}$ because water is a structural part of the formulation. Molecular immune modulators, such as CpG $(25,27)$, poly(I:C) (34), Quil-A (55), monophosphoryl lipid A (MPLA) 
(29) and imiquimod (107) have been used in dMNs. In general, a significant increase in the immune response is observed when an adjuvant is included in dMNs $(25,27)$, although sometimes the control group without the adjuvant is lacking. Unfortunately, the rationale of selection a certain adjuvant and its dose has not often been addressed.

Delivery systems can be formulated into dMNs (see previous section). Similarly to other administration routes, encapsulation of antigen (and adjuvant) in nanoparticles or liposomes can enhance the immune response after delivery with dMNs $(25,27,28)$ as described above (Humoral Immune Response and Cellular Immune Response Sections). Adjuvants are often needed with modern subunit vaccines but their use might be avoided with attenuated viruses and viral vectors. Absence of adjuvant would also facilitate batch release since adjuvant quantification is not needed and antigen quantity is often limited to a simple plaque titration or colony count as opposed to an immunogenicity test in experimental animals.

\section{MNs Spacing and MN Geometry}

Modelling studies have indicated that the MNs spacing may affect the immune response by contributing to the optimal antigen concentration released into the skin to activate APC located between the MNs (108). However, this is not experimentally confirmed and factors not accounted for in the model may contribute significantly to the immunogenicity.

The MN length may influence the population of APCs activated so that shorter MNs could activate LCs in the epidermis and longer MNs could activate dDCs in the dermis (108). In vivo studies with $1 \mu \mathrm{g}$ OVA showed that IgG response after vaccination by dMNs of 300 and $800 \mu \mathrm{m}$ in length is higher than using dMNs of $200 \mu \mathrm{m}$ in length (21). On the other hand, the variation of injection depth with hollow MNs did not affect the immune response (109). However, while a controlled antigen dose was released at different skin depth by hollow microneedles (109), not clear is the antigen dose released into the skin from the dMN of different lengths (21). This could explain the difference in the immune response.

Apart from MN length, needle density may be an important variable with respect to immunogenicity. The needles cause minor damage and cell death, initiating a pathway acting as "natural immune enhancer" mediated by the release of damage-associated molecular patterns (DAMPs) (110). In fact, the same antigen dose released by coated MNs elicited higher response than a single i.d. injection (110).

\section{CLINICAL DEVELOPMENT OF DISSOLVING MICRONEEDLES}

dMNs are a relatively new vaccine delivery system with no licensed vaccines and few results from clinical studies. Two phase 1 (safety) studies with microneedles without antigen have been performed so far. In the first, hyaluronan microneedles (length 300, 500 and $800 \mu \mathrm{m}, 200 \mathrm{dMNs}$ on a $0.8 \mathrm{~cm}^{2}$ patch) have been applied on 17 subjects (53). Despite a successful dMN penetration into the skin by using an applicator, the microneedles required $6 \mathrm{~h}$ of application for nearly complete dissolution in all subjects, which may be too long for routine immunization. In the second study, PVA microneedles (length $650 \mu \mathrm{m}, 100$ $\mathrm{dMNs}$ on a $1 \mathrm{~cm}^{2}$ patch) have been applied on 15 subjects (111). In this case, an average of $100 \%$ piercing efficiency of $\mathrm{MNs}$ into the skin without any applicator use was reached. However, variance in the microneedle volume dissolved, especially among subjects using self-administration, underlined the importance of using an applicator to have a controlled force and an impact during application. Few subjects (53) or all of them (111) showed a slight erythema after $\mathrm{dMN}$ application that disappeared within 7 days. However, longer dMNs of 500 and $800 \mu \mathrm{m}$ caused purpura, indicating capillary damage, in $50 \%$ of the volunteers but shorter $300 \mu \mathrm{m}$ dMNs did not induce any purpura (53). No swelling at the application site (111) or systemic adverse events were observed (53). Additionally, it was also concluded that $\mathrm{dMN}$ application caused hardly (53) or no pain (111).

In another clinical phase 1 study, trivalent influenza hemagglutinins vaccination with sodium hyaluronate dMNs (800 $\mu \mathrm{m}, 200 \mathrm{dMNs}$ on a $0.8 \mathrm{~cm}^{2}$ patch, spring-type applicator used) was investigated in healthy subjects (112). dMNs loaded with $3 \times 15 \mu \mathrm{g}$ of influenza antigens on a single patch, were compared with the same dose administered by s.c. injection. During the prime immunization a proper $\mathrm{dMN}$ dissolution was observed in only seven subjects out of 20 and only these subjects were included in the final analysis. Furthermore, the applicator settings were changed to obtained a more efficient application in the second vaccination. After the prime, the anti-HI antibody titers against influenza A HA-antigens (H1N1 and H3N2 strains) were equivalent in the dMN and s.c. groups, except that for the B strain that showed higher titers in the $\mathrm{dMN}$ group also observed in preclinical studies (32). More IFN- $\boldsymbol{\gamma}$-producing peripheral blood mononuclear cells were detected after s.c. than dMN immunization (112). However, the low number of subjects in $\mathrm{dMN}$ group limits the conclusions. Regarding the safety, erythema detected in the $\mathrm{dMN}$ group was higher than the s.c. one and more pronounced than in the previous clinical studies $(53,111)$. Purpura was observed in $50 \%$ of the subjects both in the $\mathrm{d} \mathrm{MN}$ and the s.c. group. However, no adverse systemic events were observed (112).

These studies prove that the applicator and its settings have a crucial role for $\mathrm{MN}$ penetration and subsequent dissolution into the skin. Alternatively, encapsulation of the antigen only in the microneedle tip can enable a complete antigen delivery 
Table IV Target Product Profile of the Ideal dMN Patch
Total systems costs lower than injected vaccine

Competitive production costs

Simple to produce

Stable outside the cold chain

Higher immunogenicity / dose sparing / single shot

Minimum waste

No applicator needed

Fail-proof application/check on full dose delivery

Short application time

Less adverse effects

Affordable

even with incomplete microneedle dissolution (e.g., localizing the antigen in the upper $70 \%$ of the MNs, a $70 \%$ dissolution would correspond to $100 \%$ antigen delivery).

Besides above mentioned studies, at least one other study has been performed to investigate safety and immunogenicity of influenza vaccination with $\mathrm{dMNs}$ but the results are not yet published (113).

\section{CONCLUSIONS AND PROSPECTS}

$\mathrm{d} M \mathrm{~N}$ vaccination can offer important advantages such as dose sparing, pain-free immunization and avoidance of needlestick injuries. Furthermore, it can extend the vaccination coverage in developing countries by potentially offering improved vaccine stability, reduction of vaccine wastage and of burden on trained personnel. However, several improvements are still needed in some areas of dMN development before the regulatory acceptance and industrial scale-up are feasible. Fabrication methods require further optimization to enable the minimal wastage of antigen that is often claimed but rarely reported in the literature, and not yet proven on at least pilot scale production level. Analytical challenges include potency testing and stability testing during fabrication and storage, and quantification and reproducibility of antigen/adjuvant dose delivered in the skin. Furthermore, the role of the applicator device should not be underestimated because it can standardize $\mathrm{dMN}$ application and vaccine delivery into the skin, although with respect to logistics manual application is preferred. dMN immunization has generated comparable or higher and more durable antibody and cellular responses than conventional immunizations in preclinical studies. Additionally, sustained release of antigen from nanoparticles or cross-linked structures in $\mathrm{dMNs}$ showed to induce a better cellular immune response than fast release from dMNs or liquid solution, although the sustained release from $\mathrm{dMNs}$ did not improve further the humoral response than fast release from dMNs. However, further studies should be performed to support this conclusion. In the future, more systematic studies, such as identification of optimal adjuvants and analysis of effect of dMN geometry, may be necessary to optimize $\mathrm{dMN}$ immunization. Until now, three clinical phase 1 studies have been reported and showed that skin irritation and patch application are hurdles that need to be solved in future applications. The ideal dMN patch (Table IV) does not exist yet but encouraging progress has been made. More work is needed to further develop dMNs into safe, efficacious, affordable and widely used products.

\section{ACKNOWLEDGEMENTS AND DISCLOSURES}

This work was sponsored by Intravacc.

Open Access This article is distributed under the terms of the Creative Commons Attribution 4.0 International License (http://creativecommons.org/licenses/by/4.0/), which permits unrestricted use, distribution, and reproduction in any medium, provided you give appropriate credit to the original author(s) and the source, provide a link to the Creative Commons license, and indicate if changes were made.

\section{REFERENCES}

1. Bal SM, Ding Z, van Riet E, Jiskoot W, Bouwstra JA. Advances in transcutaneous vaccine delivery: do all ways lead to Rome? J Control Release. 2010;148(3):266-82.

2. Hilleman MR. Vaccines in historic evolution and perspective: a narrative of vaccine discoveries. Vaccine. 2000;18(15):1436-47.

3. van der Maaden K, Jiskoot W, Bouwstra J. Microneedle technologies for (trans)dermal drug and vaccine delivery. J Control Release. 2012;161(2):645-55.

4. Kersten G, Hirschberg H. Needle-free vaccine delivery. Expert Opin Drug Del. 2007;4(5):459-74.

5. Kim YC, Park JH, Prausnitz MR. Microneedles for drug and vaccine delivery. Adv Drug Deliv Rev. 2012;64(14):1547-68. 
6. Ita K. Transdermal delivery of drugs with microneedles: strategies and outcomes. J Drug Deliv Sci Tec. 2015;29:16-23.

7. Hegde NR, Kaveri SV, Bayry J. Recent advances in the administration of vaccines for infectious diseases: microneedles as painless delivery devices for mass vaccination. Drug Discov Today. 2011;16(23-24):1061-8.

8. Hauri AM, Armstrong GL, Hutin YJF. The global burden of disease attributable to contaminated injections given in health care settings. Int J STD AIDS. 2004;15(1):7-16.

9. Engelke L, Winter G, Hook S, Engert J. Recent insights into cutaneous immunization: how to vaccinate via the skin. Vaccine. 2015;33(37):4663-74.

10. Kaurav M, Minz S, Sahu K, Kumar M, Madan J, Pandey RS. Nanoparticulate mediated transcutaneous immunization: myth or reality. Nanomedicine. 2016;12(4):1063-81.

11. Matsuo K, Hirobe S, Okada N, Nakagawa S. Frontiers of transcutaneous vaccination systems: novel technologies and devices for vaccine delivery. Vaccine. 2013;31(19):2403-15.

12. Grice EA, Segre JA. The skin microbiome. Nat Rev Microbiol. 2011;9(4):244-53.

13. Prausnitz MR, Mitragotri S, Langer R. Current status and future potential of transdermal drug delivery. Nat Rev Drug Discov. 2004;3(2):115-24.

14. Martin S. Gerstel VAP. Drug delivery device In: Patent US, editor. United States: Alza Corporation, Palo Alto, Calif.; 1976.

15. Larraneta E, McCrudden MTC, Courtenay AJ, Donnelly RF. Microneedles: a new frontier in Nanomedicine delivery. Pharm Res-Dordr. 2016;33(5):1055-73.

16. Tuan-Mahmood TM, McCrudden MTC, Torrisi BM, McAlister E, Garland MJ, Singh TRR, et al. Microneedles for intradermal and transdermal drug delivery. Eur J Pharm Sci. 2013;50(5):62337.

17. Larraneta E, Lutton REM, Woolfson AD, Donnelly RF. Microneedle arrays as transdermal and intradermal drug delivery systems: materials science, manufacture and commercial development. Mater Sci Eng R. 2016;104:1-32.

18. van der Maaden K, Luttge R, Vos PJ, Bouwstra J, Kersten G, Ploemen I. Microneedle-based drug and vaccine delivery via nanoporous microneedle arrays. Drug Deliv Transl Re. 2015;5(4):397-406.

19. Indermun S, Luttge R, Choonara YE, Kumar P, du Toit LC, Modi G, et al. Current advances in the fabrication of microneedles for transdermal delivery. J Control Release. 2014;185:130-8.

20. McCrudden MT, Alkilani AZ, McCrudden CM, McAlister E, McCarthy HO, Woolfson AD, et al. Design and physicochemical characterisation of novel dissolving polymeric microneedle arrays for transdermal delivery of high dose, low molecular weight drugs. J Control Release. 2014;180:71-80.

21. Matsuo K, Yokota Y, Zhai Y, Quan YS, Kamiyama F, Mukai Y, et al. A low-invasive and effective transcutaneous immunization system using a novel dissolving microneedle array for soluble and particulate antigens (vol 161,pg 10, 2012). J Control Release. 2014;184:9-9.

22. Hiraishi Y, Nakagawa T, Quan YS, Kamiyama F, Hirobe S, Okada $\mathrm{N}$, et al. Performance and characteristics evaluation of a sodium hyaluronate-based microneedle patch for a transcutaneous drug delivery system. Int J Pharm. 2013;441(1-2):570-9.

23. Matsuo K, Hirobe S, Yokota Y, Ayabe Y, Seto M, Quan YS, et al. Transcutaneous immunization using a dissolving microneedle array protects against tetanus, diphtheria, malaria, and influenza (vol 160, pg 495, 2012). J Control Release. 2014;184:18-9.

24. Zhu Z, Ye X, Ku Z, Liu Q, Shen C, Luo H, et al. Transcutaneous immunization via rapidly dissolvable microneedles protects against hand-foot-and-mouth disease caused by enterovirus $71 . \mathrm{J}$ Control Release. 2016;243:291-302.
25. Guo L, Chen JM, Qiu YQ Zhang SH, Xu B, Gao YH. Enhanced transcutaneous immunization via dissolving microneedle array loaded with liposome encapsulated antigen and adjuvant. Int J Pharm. 2013;447(1-2):22-30.

26. Sullivan SP, Koutsonanos DG, Martin MD, Lee JW, Zarnitsyn V, Choi SO, et al. Dissolving polymer microneedle patches for influenza vaccination. Nat Med. 2010;16(8):915-U116.

27. Qiu Y, Guo L, Zhang S, Xu B, Gao Y, Hu Y, et al. DNA-based vaccination against hepatitis $\mathrm{B}$ virus using dissolving microneedle arrays adjuvanted by cationic liposomes and CpG ODN. Drug Deliv. 2015:1-8.

28. Zaric M, Lyubomska O, Touzelet O, Poux C, Al-Zahrani S, Fay $\mathrm{F}$, et al. Skin dendritic cell targeting via microneedle arrays laden with antigen-encapsulated Poly-D,L-lactide-co-Glycolide nanoparticles induces efficient antitumor and antiviral immune responses. ACS Nano. 2013;7(3):2042-55.

29. Pattani A, McKay PF, Donnelly RF, Garland MJ, Migalska K, Cassidy CM, et al. Microneedle mediated intradermal delivery of Adjuvanted recombinant HIV-1 CN54gp140 effectively primes mucosal boost inoculations. AIDS Res Hum Retrovir. 201 1:27(10):A69-9.

30. Edens C, Dybdahl-Sissoko NC, Weldon WC, Oberste MS, Prausnitz MR. Inactivated polio vaccination using a microneedle patch is immunogenic in the rhesus macaque. Vaccine. 2015;33(37):4683-90.

31. Edens C, Collins ML, Goodson JL, Rota PA, Prausnitz MR. A microneedle patch containing measles vaccine is immunogenic in non-human primates. Vaccine. 2015;33(37):4712-8.

32. Kommareddy S, Baudner BC, Oh S, Kwon SY, Singh M, O'Hagan DT. Dissolvable microneedle patches for the delivery of cell-culture-derived influenza vaccine antigens. J Pharm Sci-Us. 2012;101(3):1021-7.

33. Bachy V, Hervouet C, Becker PD, Chorro L, Carlin LM, Herath S, et al. Langerin negative dendritic cells promote potent CD8+ T-cell priming by skin delivery of live adenovirus vaccine microneedle arrays. Proc Natl Acad Sci U S A. 2013;110(8):3041-6.

34. DeMuth PG, Garcia-Beltran WF, Ai-Ling ML, Hammond PT, Irvine DJ. Composite dissolving microneedles for coordinated control of antigen and adjuvant delivery kinetics in transcutaneous vaccination. Adv Funct Mater. 2013;23(2):161-72.

35. DeMuth PC, Min Y, Irvine DJ, Hammond PT. Implantable silk composite microneedles for programmable vaccine release kinetics and enhanced immunogenicity in transcutaneous immunization. Adv Healthc Mater. 2014;3(1):47-58.

36. Naito S, Ito Y, Kiyohara T, Kataoka M, Ochiai M, Takada K. Antigen-loaded dissolving microneedle array as a novel tool for percutaneous vaccination. Vaccine. 2012;30(6):1191-7.

37. Chen MC, Huang SF, Lai KY, Ling MH. Fully embeddable chitosan microneedles as a sustained release depot for intradermal vaccination. Biomaterials. 2013;34(12):3077-86.

38. Vrdoljak A, Allen EA, Ferrara F, Temperton NJ, Crean AM, Moore AC. Induction of broad immunity by thermostabilised vaccines incorporated in dissolvable microneedles using novel fabrication methods. J Control Release. 2016;225:192-204.

39. Bonificio A, Ghartey-Tagoe E, Gallorini S, Baudner B, Chen $\mathrm{GH}$, Singh $\mathrm{P}$, et al. Fabrication of cell culture-derived influenza vaccine dissolvable microstructures and evaluation of immunogenicity in guinea pigs. Vaccine. 2015;33(25):2930-8.

40. Vassilieva EV, Kalluri H, McAllister D, Taherbhai MT, Esser ES, Pewin WP, et al. Improved immunogenicity of individual influenza vaccine components delivered with a novel dissolving microneedle patch stable at room temperature. Drug Deliv Transl Re. 2015;5(4):360-71.

41. Arya JM, Dewitt K, Scott-Garrard M, Chiang YW, Prausnitz MR. Rabies vaccination in dogs using a dissolving microneedle patch. J Control Release. 2016;239:19-26. 
42. Allen EA, O'Mahony C, Cronin M, O'Mahony T, Moore AG, Crean AM. Dissolvable microneedle fabrication using piezoelectric dispensing technology. Int J Pharm. 2016;500(1-2):1-10.

43. Quinn HL, Bonham L, Hughes CM, Donnelly RF. Design of a Dissolving Microneedle Platform for transdermal delivery of a fixed-dose combination of cardiovascular drugs. J Pharm Sci-Us. 2015;104(10):3490-500.

44. Caffarel-Salvador E, Kearney MC, Mairs R, Gallo L, Stewart SA, Brady AJ, et al. Methylene blue-loaded dissolving microneedles: potential use in photodynamic antimicrobial chemotherapy of infected wounds. Pharmaceutics. 2015;7(4):397-412.

45. Gomaa YA, Garland MJ, McInnes F, El-Khordagui LK, Wilson C, Donnelly RF. Laser-engineered dissolving microneedles for active transdermal delivery of nadroparin calcium. Eur J Pharm Biopharm. 2012;82(2):299-307.

46. Wu X, Chen Y, Gui S, Wu X, Chen L, Cao Y, et al. Sinomenine hydrochloride-loaded dissolving microneedles enhanced its absorption in rabbits. Pharm Dev Technol. 2015:1-7.

47. Vemulapalli V, Yang Y, Friden PM, Banga AK. Synergistic effect of iontophoresis and soluble microneedles for transdermal delivery of methotrexate. J Pharm Pharmacol. 2008;60(1):27-33.

48. McGrath MG, Vucen S, Vrdoljak A, Kelly A, O'Mahony C, Crean AM, et al. Production of dissolvable microneedles using an atomised spray process: effect of microneedle composition on skin penetration. Eur J Pharm Biopharm. 2014;86(2):200-11.

49. Park JH, Choi SO, Seo S, Choy YB, Prausnitz MR. A microneedle roller for transdermal drug delivery. Eur J Pharm Biopharm. 2010;76(2):282-9.

50. Park JH, Allen MG, Prausnitz MR. Biodegradable polymer microneedles: fabrication, mechanics and transdermal drug delivery. Conf Proc IEEE Eng Med Biol Soc. 2004;4:2654-7.

51. Chu LY, Choi SO, Prausnitz MR. Fabrication of dissolving polymer microneedles for controlled drug encapsulation and delivery: bubble and pedestal microneedle designs. J Pharm Sci. 2010;99(10):4228-38.

52. Liu S, Jin MN, Uuan YSQ Kamiyama F, Kusamori K, Katsumi $\mathrm{H}$, et al. Transdermal delivery of relatively high molecular weight drugs using novel self-dissolving microneedle arrays fabricated from hyaluronic acid and their characteristics and safety after application to the skin. Eur J Pharm Biopharm. 2014;86(2):267-76.

53. Hirobe S, Azukizawa H, Matsuo K, Zhai Y, Quan YS, Kamiyama F, et al. Development and clinical study of a selfdissolving microneedle patch for transcutaneous immunization device. Pharm Res-Dordr. 2013;30(10):2664-74.

54. Liu S, Jin MN, Quan YS, Kamiyama F, Katsumi H, Sakane T, et al. The development and characteristics of novel microneedle arrays fabricated from hyaluronic acid, and their application in the transdermal delivery of insulin. J Control Release. 2012;161(3):933-41.

55. Raphael AP, Prow TW, Crichton ML, Chen XF, Fernando GIP, Kendall MAF. Targeted, needle-free vaccinations in skin using multi layered. Densely-Packed Dissolving Microprojection Arrays Small. 2010;6(16):1785-93.

56. Lippmann JM, Geiger EJ, Pisano AP. Polymer investment molding: method for fabricating hollow, microscale parts. Sensor Actuat a-Phys. 2007;134(1):2-10.

57. Perennes F, Marmiroli B, Matteucci M, Tormen M, Vaccari L, Di Fabrizio E. Sharp beveled tip hollow microneedle arrays fabricated by LIGA and 3D soft lithography with polyvinyl alcohol. J Micromech Microeng. 2006;16(3):473-9.

58. Lee J, Park SH, Seo IH, Lee KJ, Ryu W. Rapid and repeatable fabrication of high $\mathrm{a} / \mathrm{R}$ silk fibroin microneedles using thermallydrawn micromolds. Eur J Pharm Biopharm. 2015;94:11-9.

59. Gomaa YA, Morrow DI, Garland MJ, Donnelly RF, ElKhordagui LK, Meidan VM. Effects of microneedle length, density, insertion time and multiple applications on human skin barrier function: assessments by transepidermal water loss. Toxicol in Vitro. 2010;24(7):1971-8.

60. Park Y, ParkJ, Chu GS, Kim KS, Sung JH, Kim B. Transdermal delivery of cosmetic ingredients using dissolving polymer microneedle arrays. Biotechnol Bioproc E. 2015;20(3):543-9.

61. Monkare J, Reza Nejadnik M, Baccouche K, Romeijn S, Jiskoot W, Bouwstra JA. IgG-loaded hyaluronan-based dissolving microneedles for intradermal protein delivery. J Control Release. 2015;218:53-62.

62. Wang QQ Yao GT, Dong P, Gong ZH, Li G, Zhang KJ, et al. Investigation on fabrication process of dissolving microneedle arrays to improve effective needle drug distribution. Eur J Pharm Sci. 2015;66:148-56.

63. Chu LY, Prausnitz MR. Separable arrowhead microneedles. J Control Release. 2011;149(3):242-9.

64. Ita K. Transdermal delivery of drugs with microneedles-potential and challenges. Pharmaceutics. 2015;7(3):90-105.

65. Lee K, Jung H. Drawing lithography for microneedles: a review of fundamentals and biomedical applications. Biomaterials. 2012;33(30):7309-26.

66. Lee K, Lee CY, Jung H. Dissolving microneedles for transdermal drug administration prepared by stepwise controlled drawing of maltose. Biomaterials. 2011;32(11):3134-40.

67. Moga KA, Bickford LR, Geil RD, Dunn SS, Pandya AA, Wang YP, et al. Rapidly-dissolvable microneedle patches via a highly scalable and reproducible soft lithography approach. Adv Mater. 2013;25(36):5060-6.

68. Kim JD, Kim M, Yang H, Lee K, Jung H. Droplet-born air blowing: novel dissolving microneedle fabrication. J Control Release. 2013;170(3):430-6.

69. Yang H, Kim S, Huh I, Kim S, Lahiji SF, Kim M, et al. Rapid implantation of dissolving microneedles on an electrospun pillar array. Biomaterials. 2015;64:70-7.

70. McCaffrey J, McCrudden CM, Ali AA, Massey AS, McBride JW, McCrudden MTC, et al. Transcending epithelial and intracellular biological barriers; a prototype DNA delivery device. J Control Release. 2016;226:238-47.

71. Xiang ZL, Wang H, Pant A, Pastorin G, Lee C. Development of vertical SU-8 microtubes integrated with dissolvable tips for transdermal drug delivery. Biomicrofluidics. 2013;7(2)

72. Narayan RJ, Doraiswamy A, Chrisey DB, Chichkov BN. Medical prototyping using two photon polymerization. Mater Today. 2010;13(12):42-8.

73. Kochhar JS, Goh WJ, Chan SY, Kang LF. A simple method of microneedle array fabrication for transdermal drug delivery. Drug Dev Ind Pharm. 2013;39(2):299-309.

74. Kochhar JS, Zou S, Chan SY, Kang LF. Protein encapsulation in polymeric microneedles by photolithography. Int J Nanomedicine. 2012;7:3143-54.

75. Gittard SD, Ovsianikov A, Akar H, Chichkov B, MonteiroRiviere NA, Stafslien S, et al. Two photon polymerizationMicromolding of polyethylene glycol-gentamicin sulfate microneedles. Adv Eng Mater. 2010;12(4):B77-82.

76. Prestrelski SJ, Tedeschi N, Arakawa T, Carpenter JF. Dehydration-induced conformational transitions in proteins and their inhibition by stabilizers. Biophys J. 1993;65(2):661-71.

77. McCrudden MTC, Alkilani AZ, Courtenay AJ, McCrudden CM, McCloskey B, Walker C, et al. Considerations in the sterile manufacture of polymeric microneedle arrays. Drug Deliv Transl Re. 2015;5(1):3-14.

78. Guidance for industry, pyrogen and endotoxin testing question and answers 2012. In.; 2014.

79. European Pharmacopeia; 2013

80. Lee JW, Park JH, Prausnitz MR. Dissolving microneedles for transdermal drug delivery. Biomaterials. 2008;29(13):2113-24. 
81. Thakur RR, Tekko IA, Al-Shammari F, Ali AA, McCarthy H, Donnelly RF. Rapidly dissolving polymeric microneedles for minimally invasive intraocular drug delivery. Drug Deliv Transl Res. 2016;6(6):800-15.

82. Kim YPB. Skin permeability of compounds loaded within dissolving microneedles dependent on composition of sodium hyaluronate and carboxymethyl cellulose. Korean J Chem Eng. 2016:1-6.

83. Demir YK, Akan Z, Kerimoglu O. Characterization of polymeric microneedle arrays for transdermal drug delivery. PLoS One. 2013;8(10):e77289.

84. Donnelly RF, Morrow DI, Fay F, Scott CJ, Abdelghany S, Singh $\mathrm{RR}$, et al. Microneedle-mediated intradermal nanoparticle delivery: potential for enhanced local administration of hydrophobic pre-formed photosensitisers. Photodiagn Photodyn Ther. 2010;7(4):222-31.

85. Mistilis MJ, Bommarius AS, Prausnitz MR. Development of a thermostable microneedle patch for influenza vaccination. J Pharm Sci-Us. 2015;104(2):740-9.

86. Kommareddy S, Baudner BC, Oh S, Kwon SY, Singh M, O'Hagan DT. Dissolvable microneedle patches for the delivery of cell-culture-derived influenza vaccine antigens. J Pharm Sci. 2012;101(3):1021-7.

87. Davis SP, Landis BJ, Adams ZH, Allen MG, Prausnitz MR. Insertion of microneedles into skin: measurement and prediction of insertion force and needle fracture force. J Biomech. 2004;37(8):1 155-63.

88. Sullivan SP, Murthy N, Prausnitz MR. Minimally invasive protein delivery with rapidly dissolving polymer microneedles. Adv Mater. 2008;20(5):933-8.

89. Moronkeji K, Todd S, Dawidowska I, Barrett SD, Akhtar R. The role of subcutaneous tissue stiffness on microneedle performance in a representative in vitro model of skin.J Control Release. 2016;

90. Larraneta E, Stewart S, Fallows SJ, Birkhauer LL, McCrudden MT, Woolfson AD, et al. A facile system to evaluate in vitro drug release from dissolving microneedle arrays. Int J Pharm. 2016;497(1-2):62-9.

91. van der Maaden K, Varypataki EM, Romeijn S, Ossendorp F, Jiskoot W, Bouwstra J. Ovalbumin-coated $\mathrm{pH}$-sensitive microneedle arrays effectively induce ovalbumin-specific antibody and T-cell responses in mice. Eur J Pharm Biopharm. 2014;88(2):310-5.

92. De Koker S, De Geest BG, Singh SK, De Rycke R, Naessens T, Van Kooyk Y, et al. Polyelectrolyte microcapsules as antigen delivery vehicles to dendritic cells: uptake, processing, and crosspresentation of encapsulated antigens. Angew Chem Int Ed. 2009;48(45):8485-9.

93. Jung S, Unutmaz D, Wong P, Sano G. De los Santos K, Sparwasser T, Wu S, Vuthoori S, Ko K, Zavala F, Pamer EG, Littman DR, Lang RA. In vivo depletion of CD1 lc+ dendritic cells abrogates priming of CD8+ $\mathrm{T}$ cells by exogenous cellassociated antigens. Immunity. 2002;17(2):211-20.

94. Badovinac VP, Haring JS, Harty JT. Initial T cell receptor transgenic cell precursor frequency dictates critical aspects of the CD8(+) T cell response to infection. Immunity. 2007;26(6):82741.

95. Verbaan FJ, Bal SM, van den Berg DJ, Groenink WHH, Verpoorten H, Luttge R, et al. Assembled microneedle arrays enhance the transport of compounds varying over a large range of molecular weight across human dermatomed skin. J Control Release. 2007;117(2):238-45.

96. Verbaan FJ, Bal SM, van den Berg DJ, Dijksman JA, van Hecke $\mathrm{M}$, Verpoorten $\mathrm{H}$, et al. Improved piercing of microneedle arrays in dermatomed human skin by an impact insertion method. J Control Release. 2008;128(1):80-8.
97. van der Maaden K, Sekerdag E, Jiskoot W, Bouwstra J. Impactinsertion applicator improves reliability of skin penetration by solid microneedle arrays. AAPS J. 2014;16(4):681-4.

98. Sugimoto Y, Sanuki S, Ohsako S, Higashimoto Y, Kondo M, Kurawaki J, et al. Ovalbumin in developing chicken eggs migrates from egg white to embryonic organs while changing its conformation and thermal stability. J Biol Chem. 1999;274(16):11030-7.

99. van der Maaden K, Varypataki EM, Yu H, Romeijn S, Jiskoot W, Bouwstra J. Parameter optimization toward optimal microneedlebased dermal vaccination. Eur J Pharm Sci. 2014;64:18-25.

100. Becker PD, Hervouet G, Mason GM, Kwon SY, Klavinskis LS. Skin vaccination with live virus vectored microneedle arrays induce long lived CD8(+) T cell memory. Vaccine. 2015;33(37):4691-8.

101. Carey JB, Pearson FE, Vrdoljak A, McGrath MG, Crean AM, Walsh PT, et al. Microneedle array design determines the induction of protective memory CD8+ T cell responses induced by a recombinant live malaria vaccine in mice. PLoS One. 2011;6(7):e22442.

102. Koutsonanos DG, del Pilar MM, Zarnitsyn VG, Jacob J, Prausnitz MR, Compans RW, et al. Serological memory and long-term protection to novel $\mathrm{H} 1 \mathrm{Nl}$ influenza virus after skin vaccination. J Infect Dis. 201 1;204(4):582-91.

103. Ochsenbein AF, Karrer U, Klenerman P, Althage A, Ciurea A, Shen $\mathrm{H}$, et al. A comparison of $\mathrm{T}$ cell memory against the same antigen induced by virus versus intracellular bacteria. Proc Natl Acad Sci U S A. 1999;96(16):9293-8.

104. Demento SL, Gui W, Criscione JM, Stern E, Tulipan J, Kaech $\mathrm{SM}$, et al. Role of sustained antigen release from nanoparticle vaccines in shaping the $\mathrm{T}$ cell memory phenotype. Biomaterials. 2012;33(19):4957-64.

105. Zaric M, Lyubomska O, Poux C, Hanna ML, McCrudden MT, Malissen B, et al. Dissolving microneedle delivery of nanoparticleencapsulated antigen elicits efficient cross-priming and Th1 immune responses by murine Langerhans cells. J Invest Dermatol. 2015;135(2):425-34.

106. Vogelbruch M, Nuss B, Korner M, Kapp A, Kiehl P, Bohm W. Aluminium-induced granulomas after inaccurate intradermal hyposensitization injections of aluminium-adsorbed depot preparations. Allergy. 2000;55(9):883-7.

107. McCrudden MT, Torrisi BM, Al-Zahrani S, McCrudden CM, Zaric M, Scott CJ, et al. Laser-engineered dissolving microneedle arrays for protein delivery: potential for enhanced intradermal vaccination. J Pharm Pharmacol. 2015;67(3):409-25.

108. Romgens AM, Bader DL, Bouwstra JA, Oomens CW. Predicting the optimal geometry of microneedles and their array for dermal vaccination using a computational model. Comput Methods Biomech Biomed Engin. 2016;19(15):1599-609.

109. Schipper P, van der Maaden K, Romeijn S, Oomens C, Kersten $\mathrm{G}$, Jiskoot W, et al. Determination of depth-dependent intradermal immunogenicity of Adjuvanted inactivated polio vaccine delivered by microinjections via hollow microneedles. Pharm Res. 2016;33(9):2269-79.

110. Depelsenaire ACI, Meliga SC, McNeilly CL, Pearson FE, Coffey JW, Haigh OL, et al. Colocalization of cell death with antigen deposition in skin enhances vaccine immunogenicity. J Invest Dermatol. 2014;134(9):2361-70.

111. Arya J, Henry S, Kalluri H, McAllister DV, Pewin WP, Prausnitz MR. Tolerability, usability and acceptability of dissolving microneedle patch administration in human subjects. Biomaterials. 2017;128:1-7.

112. Hirobe S, Azukizawa H, Hanafusa T, Matsuo K, Quan YS, Kamiyama F, et al. Clinical study and stability assessment of a novel transcutaneous influenza vaccination using a dissolving microneedle patch. Biomaterials. 2015;57:50-8.

113. A Phase I Study of the Safety, Reactogenicity, Acceptability and Immunogenicity of Inactivated Influenza Vaccine Delivered by Microneedle Patch or by Hypodermic Needle. In.; 2015. 